\title{
Origin and radiative forcing of black carbon transported to the Himalayas and Tibetan Plateau
}

\author{
M. Kopacz ${ }^{1}$, D. L. Mauzerall ${ }^{1,2}$, J. Wang ${ }^{3}$, E. M. Leibensperger ${ }^{4}$, D. K. Henze ${ }^{5}$, and K. Singh ${ }^{6}$ \\ ${ }^{1}$ Woodrow Wilson School of Public and International Affairs, Princeton University, Princeton, NJ, USA \\ ${ }^{2}$ Department of Civil and Environmental Engineering, Princeton University, Princeton, NJ, USA \\ ${ }^{3}$ Department of Earth and Atmospheric Sciences, University of Nebraska-Lincoln, Lincoln, NE, USA \\ ${ }^{4}$ School of Engineering and Applied Science, Harvard University, Cambridge, MA, USA \\ ${ }^{5}$ Mechanical Engineering Department, University of Colorado-Boulder, Boulder, CO, USA \\ ${ }^{6}$ Computer Science Department, Virginia Polytechnic University, Blacksburg, VA, USA
}

Received: 1 September 2010 - Published in Atmos. Chem. Phys. Discuss.: 13 September 2010

Revised: 1 March 2011 - Accepted: 7 March 2011 - Published: 25 March 2011

\begin{abstract}
The remote and high elevation regions of central Asia are influenced by black carbon (BC) emissions from a variety of locations. $\mathrm{BC}$ deposition contributes to melting of glaciers and questions exist, of both scientific and policy interest, as to the origin of the $\mathrm{BC}$ reaching the glaciers. We use the adjoint of the GEOS-Chem model to identify the location from which $\mathrm{BC}$ arriving at a variety of locations in the Himalayas and Tibetan Plateau originates. We then calculate its direct and snow-albedo radiative forcing. We analyze the seasonal variation in the origin of $\mathrm{BC}$ using an adjoint sensitivity analysis, which provides a detailed map of the location of emissions that directly contribute to black carbon concentrations at receptor locations. We find that emissions from northern India and central China contribute the majority of $\mathrm{BC}$ to the Himalayas, although the precise location varies with season. The Tibetan Plateau receives most BC from western and central China, as well as from India, Nepal, the Middle East, Pakistan and other countries. The magnitude of contribution from each region varies with season and receptor location. We find that sources as varied as African biomass burning and Middle Eastern fossil fuel combustion can significantly contribute to the $\mathrm{BC}$ reaching the Himalayas and Tibetan Plateau. We compute radiative forcing in the snow-covered regions and find the forcing due to the $\mathrm{BC}$ induced snow-albedo effect to vary from $5-15 \mathrm{~W} \mathrm{~m}^{-2}$ within the region, an order of magnitude larger than radiative forcing due to the direct effect, and with significant seasonal variation in the northern Tibetan Plateau. Radiative forcing from
\end{abstract}

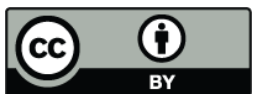

Correspondence to: D. L. Mauzerall (mauzeral@princeton.edu) reduced snow albedo likely accelerates glacier melting. Our analysis may help inform mitigation efforts to slow the rate of glacial melt by identifying regions that make the largest contributions to $\mathrm{BC}$ deposition in the Himalayas and Tibetan Plateau.

\section{Introduction}

Black carbon (BC) emissions have been found to be important contributors to current global warming (Forster et al., 2007; Ramanathan and Carmichael, 2008). However, calculating the full effect of $\mathrm{BC}$ emissions on global climate is complex as a myriad of effects (direct, indirect, semi-direct and snow-albedo effect) and source types (industrial, diesel, stoves, open biomass burning, etc.) influence the final radiative forcing. Substantial research is currently underway to quantify the radiative forcing (RF) of $\mathrm{BC}$ from its varied sources and effects. Recent research has shown emissions of $\mathrm{BC}$ that are co-emitted with scattering aerosols such as organic carbon (OC) and sulfate result in lower (and possibly negative) radiative forcing than $\mathrm{BC}$ emitted alone (Aunan et al., 2009; Bauer et al., 2010; Ramana et al., 2010). However, internal mixing of $\mathrm{BC}$ with scattering aerosols likely increases the RF of the BC (Jacobson, 2001). In addition, the distribution of $\mathrm{BC}$ after it is emitted influences its warming efficacy, where the efficacy is the global temperature response per unit forcing relative to the response to $\mathrm{CO}_{2}$ forcing (Hansen et al., 2005). Kopp and Mauzerall (2010) performed a meta analysis reconciling recent radiative forcing estimates and concluded that $\mathrm{BC}$ emissions from contained combustion (which emits little OC) result in positive RF,

Published by Copernicus Publications on behalf of the European Geosciences Union. 
while there is a low probability that carbonaceous aerosols from open biomass burning (which co-emits substantial OC) have a positive RF. However, whether the RF from the indirect effect of $\mathrm{BC}$ is warming or cooling has not yet been fully constrained (Jacobson, 2006; Forster et al., 2007; Chen et al., 2010). There is agreement, however, that BC depositing on snow and ice covered regions has a large positive RF. The efficacy of RF due to BC deposition on snow is estimated to be 236\% (Hansen et al., 2005) with deposition of $\mathrm{BC}$ on snow and ice reducing the snow's albedo and increasing melting rates (Hansen and Nazarenko, 2005; Quinn et al., 2008; Ramanathan and Carmichael 2008; Shindell and Faluvegi, 2009; Flanner et al., 2009).

Identifying the locations from which the $\mathrm{BC}$ that deposits in snow covered regions originates would be valuable in prioritizing mitigation efforts as this BC clearly contributes to warming. However, modeling global transport and radiative forcing of $\mathrm{BC}$ poses numerous challenges. Past, present and future emissions of aerosols in general and $\mathrm{BC}$ in particular are highly uncertain (Bond et al., 2007, 2004; Shindell et al., 2008). The conversion rate from the hydrophobic to hydrophilic form of $\mathrm{BC}$ can have a large effect on the lifetime and thus transport of $\mathrm{BC}$ and incorporation of the physics of that transformation in models is just starting (Liu et al., 2011). For example, only 5 out of the 17 AEROCOM models include physical aging of BC (Koch et al., 2009b). Complicated cloud microphysics and BC effects on clouds (semidirect and indirect effects) add large uncertainties to both BC concentrations and radiative forcing (Allen and Sherwood, 2010; Bauer et al., 2010). Finally, measurements of BC with which to evaluate the models are limited and the use of different measurement techniques (thermal vs. thermal optical) may result in variation in measured quantities (Vignati et al., 2010). All these difficulties contribute to a mix of model underestimates and overestimates when compared to observations as well as a large range for $\mathrm{BC}$ total radiative forcing (RF), $+0.02 \pm 1 \mathrm{~W} \mathrm{~m}^{-2}$ (Koch et al., 2009b; Kopp and Mauzerall, 2010). Some of the recent estimates of snowalbedo effect alone are $+0.05 \mathrm{~W} \mathrm{~m}^{-2}$ globally (Hansen et al., 2005) and as high as $+20 \mathrm{~W} \mathrm{~m}^{-2}$ during spring in parts of the Tibetan Plateau (Flanner et al., 2007).

The Himalayas and the Tibetan Plateau, also collectively known as the Third Pole, represent a large area of seasonal and permanent snow cover. They are surrounded by growing emissions of Asian air pollutants, and observations of BC content in snow show a rapidly increasing trend $(\mathrm{Xu}$ et al., 2009a). Here we connect observations of BC concentrations in the snow-covered regions to the surrounding emissions by tracking from where the $\mathrm{BC}$ at the Third Pole originates. We also calculate the direct and snow-albedo RF of BC in the snow-covered parts of the Himalayas and the Tibetan Plateau. Several studies attempted to quantify the sources that contribute $\mathrm{BC}$ to the Asian glacier region through a mix of forward modeling (Menon et al., 2010; Ramanathan and Carmichael, 2008) and back trajectory modeling (Ming et al.,
2008, 2009). Menon et al. (2010) used two recent BC emission inventories for India to assess the effect of $\mathrm{BC}$ aerosols on snow cover. Ramanathan and Carmichael (2008) studied the impact of biofuel $\mathrm{BC}$ emissions in India on regional radiative forcing, while Ming et al. $(2008,2009)$ employed back trajectory analysis to map the regions from which $\mathrm{BC}$ in the Third Pole snow was transported. Here we use an adjoint model that improves on these approaches by identifying both the exact location (model grid box) from which BC is emitted and the quantity of emissions from each grid box that arrived at the receptor grid box.

Our goals in this paper are thus to: (1) provide a spatially and seasonally resolved estimate of the origin of BC arriving at the Third Pole; and (2) estimate radiative forcing due to $\mathrm{BC}$ at the Third Pole. Identifying the regions from which $\mathrm{BC}$ originates will suggest target areas for $\mathrm{BC}$ mitigation that have the largest potential co-benefits for both climate and local air quality. In our study, we employ the GEOS-Chem adjoint model and a four-stream broadband radiative transfer model to characterize the origin of $\mathrm{BC}$ and its associated RF, respectively. In Sect. 2, we describe the models; in Sect. 3 we evaluate the model BC surface concentrations with available ice core and surface snow measurements; in Sect. 4, we analyze radiative forcing results; in Sect. 5 we discuss the $\mathrm{BC}$ contributions from various regions to the Third Pole as calculated by the adjoint model; we conclude in Sect. 6. This is the first adjoint receptor modeling study focused on the Third Pole.

\section{Models}

\subsection{GEOS-Chem global chemical Transport Model (CTM) and its adjoint}

GEOS-Chem is a global chemical transport model (CTM) (http://geos-chem.org/), which solves the continuity equation in individual model grid boxes. It is driven by assimilated meteorology from NASA/GMAO. Here we use v8-0203 with GEOS4 meteorological fields, which have a native resolution of $1 \times 1^{\circ}$ and 48 vertical layers from the surface to $0.01 \mathrm{hPa}$. For computational expediency, we degrade the resolution to $2 \times 2.5^{\circ}$ and 30 vertical layers. Over the past several years, GEOS-Chem has been used extensively and successfully to study long range transport of pollution (Fisher et al., 2010; Heald et al., 2003; Li et al., 2002; Zhang et al., 2008). While the relatively coarse resolution cannot provide detailed information of the intra Himalayan and Tibetan Plateau transport, GEOS-Chem can illuminate regional and inter-continental transport of pollution to the Third Pole.

We use the Bond et al. (2004) global BC emissions inventory with $8 \mathrm{Tg}$ global annual emissions, of which $38 \%$ comes from fossil fuel, $20 \%$ from biofuel and $42 \%$ from open burning. We overwrite the emissions from open burning with biomass burning emissions from the GFED2 inventory (van 
der Werf et al., 2006). Biomass burning emissions in 2001 in Africa can be characterized as typical, with a standard deviation of only 10\% between 1997-2004 (van der Werf et al., 2006). Thus the interannual variability of BC emissions from Africa to the Third Pole depends mostly on variability in meteorology. BC is emitted in hydrophobic and hydrophilic states in a 4:1 ratio, with a conversion time constant of 1.15 days (Park et al., 2005). We simulate BC concentrations and deposition for 1 January-31December 2001, following several months of spin-up. Year 2001 was a year without a strong north Atlantic Oscillation (NAO) signal.

The GEOS-Chem adjoint model provides efficient computation of source-receptor sensitivities (Henze et al., 2007). It is derived from the GEOS-Chem (Bey et al., 2001) CTM. The adjoint has been developed and previously used to estimate the magnitude of aerosol (Henze et al., 2009) and CO sources (Henze et al., 2007; Kopacz et al., 2010; Kopacz et al., 2009) and to compute local, upwind and chemical sources of pollution at a particular site (Henze et al., 2009; Zhang et al., 2009). Here we use the adjoint model as a tool to compute the sensitivity of $\mathrm{BC}$ concentrations (y) in the atmospheric column above a certain model grid box, including the fraction that deposits, to global emissions of BC. This sensitivity is denoted as $\mathbf{K}$ in Equation (1) below and is a unitless quantity.

$\mathbf{y}=\mathbf{K x}$

As the BC model simulation is linear, multiplication of the sensitivity (K) by emissions ( $\mathbf{x}$ ) yields an estimate of how much BC emissions from each model grid box contribute to concentrations and deposition in a receptor grid box $(\mathbf{y})$. The resulting units are thus units of mass and can be averaged, as we do here, over the time period of our simulations. We select five receptor grid boxes, for which $\mathrm{BC}$ measurements in snow and glaciers exist (as seen in Fig. 1 and discussed in Sect. 3). For each $2 \times 2.5^{\circ}$ latitude $\times$ longitude receptor grid box, we compute the emission contributions within the column over the course of a two week simulation. To assess the seasonality of these contributions, we perform four simulations for each receptor location, across four seasons: dry/winter (January), pre-monsoon/spring (April), monsoon/summer (July), postmonsoon/fall (October). Each adjoint simulation spans the first two weeks of the corresponding month in 2001. Our simulations are performed with the recently updated v8 of the GEOS-Chem adjoint (http://wiki.seas.harvard.edu/ geos-chem/index.php/GEOS-Chem_Adjoint).

\subsection{Radiative Transfer Model (RTM)}

A four-stream radiative transfer model is used to compute the top-of-atmosphere forcings respectively of the atmospheric $\mathrm{BC}$ and the change of surface albedo induced by the deposition of BC. The model is a plane-parallel broadband radiative transfer model, originally designed to calculate the atmo-

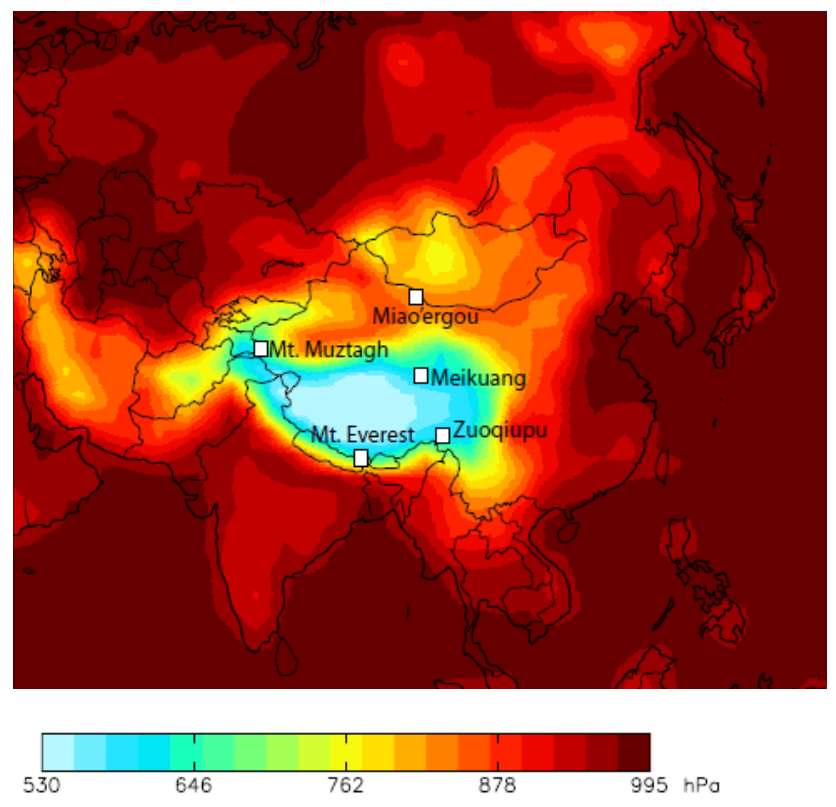

Fig. 1. Location of the five glacier sites in the Himalayas and the Tibetan Plateau that we use as receptors in this study. Annual mean surface pressure from GEOS-Chem is overlaid. We compare measured concentrations of $\mathrm{BC}$ in snow at these sites with concentrations simulated by GEOS-Chem.

spheric radiative transfer in clear and cloudy conditions $(\mathrm{Fu}$ and Liou, 1993), which was later modified for calculation of radiative forcing of aerosols, such as smoke (Wang and Christopher, 2006), dust (Wang et al., 2004), and sulfate particles (Wang et al., 2008). The gas absorption, water vapor absorption and Rayleigh scattering are included in the model calculations. The calculation also uses monthly mean surface reflectance data (Koelemeijer et al., 2003). For the principal atmospheric gases, the difference between the four-stream and line-by-line irradiance calculations is within $0.05 \%$ (Fu and Liou, 1993). Overall, for the computations of solar irradiance covering the entire short wave spectrum, the calculated values are within 5\% for the adding-doubling calculations (Liou et al., 1988). Previous studies show an excellent agreement between the calculated and observed downward shortwave irradiance at the surface, with differences of $<3 \%$ when aerosol effects are carefully considered in the radiative transfer calculations (Wang et al., 2004).

In this study, the radiative transfer calculation is conducted every $6 \mathrm{~h}$ for the corresponding GEOS-Chem simulated 3$\mathrm{D}$ aerosol distributions and GMAO's atmospheric profiles of water vapor, temperature, and pressure. The single scattering properties of $\mathrm{BC}$ are adopted from Wang and Martin (2007). The difference between upwelling radiative fluxes with and without (BC) aerosols yields a clear sky direct radiative forcing, which can then be augmented by cloud fraction to yield the full sky radiative forcing estimate (Wang et al., 2008). Here, we report clear-sky radiative forcing 
unless otherwise indicated. The model assumes external mixing of aerosols, which gives a lower-bound estimate of radiative forcing from $\mathrm{BC}$ which, in the real atmosphere, could be internally mixed with scattering aerosols (Hansen et al., 2005; Jacobson, 2001). In addition to direct radiative forcing, we compute snow-albedo radiative forcing from the spectrally averaged albedo changes due to $\mathrm{BC}$ deposition on snow (Warren and Wiscombe, 1985). To compute snowalbedo radiative forcing, we first compute radiative forcing with unperturbed MODIS-derived surface albedo. We then add the albedo change we computed to have resulted from $\mathrm{BC}$ deposition, and again calculate radiative forcing. The difference between the two forcing calculations is our linear approximation of the radiative forcing due to the snow-albedo effect.

\section{BC at the Third Pole: simulated vs. observed}

We simulate $\mathrm{BC}$ concentrations and deposition to snow in the Himalayas and the Tibetan Plateau using GEOS-Chem. To date, GEOS-Chem BC concentrations have only been evaluated over the United States using the Interagency Monitoring of Protected Visual Environments (IMPROVE) network surface measurements in national parks and protected areas (Park et al., 2006; E. Leibensperger, personal communication, 2011) and in the Arctic using data from NASA's Arctic Research of the Composition of the Troposphere from Aircraft and Satellites (ARCTAS) aircraft campaign during spring and summer of 2008 (Q. Wang, personal communication, 2011). In the remote regions of the Himalayas and the Tibetan Plateau, model evaluation is critical due to complex topography and meteorology. As a relatively coarse resolution global model, GEOS-Chem cannot resolve individual mountain peaks and valleys or the complicated air flow within them. We thus do not attempt to resolve such flow, focusing instead on GEOS-Chem and its adjoint's documented ability to accurately represent long range transport of pollution, as mentioned in Sect. 2. As can be seen from maps of emissions, surface concentrations, and wind patterns (Figs. 2 and 3), the largest sources and surface concentrations of $\mathrm{BC}$ are near densely populated regions, from which $\mathrm{BC}$ can be transported to the Third Pole. To evaluate GEOS-Chem's ability to simulate this BC transport and deposition accurately, we compare GEOS-Chem's simulated BC concentrations in the Third Pole to available observations.

Here we use $\mathrm{BC}$ measurements in precipitation and surface snow to evaluate the ability of GEOS-Chem to simulate BC content in the snow of the Himalayas and Tibetan Plateau. The observations (Ming et al., 2008, 2009; Xu et al., 2009a, b, 2006) span several years (and seasons) and we limit our comparison to those taken or dated after 1990. Model-data comparison in this case evaluates not only the accuracy of the emission inventory and GEOS-Chem's ability to simulate $\mathrm{BC}$ concentrations in the snow, but also the accuracy of meteorological data in correctly estimating the amount and timing of precipitation. The modeled quantity here is the ratio of the total amount of $\mathrm{BC}$ deposited to the total amount of precipitation. We assume that this approximates $\mathrm{BC}$ concentration in surface snow at all times, neglecting the potentially significant effect of snow aging.

Table 1 shows the comparison between simulated and observed BC content in snow across the Third Pole. There is a large variation in measured concentrations with location and season, from the low value of $0.3 \mu \mathrm{g} \mathrm{kg}^{-1}$ in summer surface snow in Namunani (western Himalayas), to $111 \mu \mathrm{g} \mathrm{kg}^{-1}$ and $446 \mu \mathrm{gg}^{-1}$ during the summer in the north and northeastern Tibetan Plateau. BC concentration in snow on the Tibetan Plateau is a factor of 2-3 lower during the monsoon than during the non-monsoon season where observations across seasons are available. Thus the highest concentrations reported here could conceivably be higher if pre-monsoon observations for these sites were available. Generally, the model identifies the seasonal and spatial variation of the concentrations across the diverse region, but the individual data point comparisons reveal under- and over-estimates ranging from $10 \%$ to a factor of 3 with no systematic bias. Two exceptions are Meikuang and La'nong, where observations indicate exceptionally high $\mathrm{BC}$ concentrations. These sites neighbor local sources (Ming et al., 2009; Xu et al., 2006) which the global model does not capture. Large seasonal variation in BC concentrations has been previously reported both in snow (Ming et al., 2009) and air (Marinoni et al., 2010). We find that, in fact, BC deposition is low (high) throughout the monsoon (non-monsoon) season, generally May-October (November-April). Although the concentrations here depend on both the amount of $\mathrm{BC}$ and precipitation, for the Everest site, the highest $\mathrm{BC}$ deposition occurs during the monsoon, reflecting scavenging near the source regions, whereas deposition of $\mathrm{BC}$ at other sites peaks in non-monsoon seasons.

In order to identify and quantify the variety of regional and seasonal sources of $\mathrm{BC}$ to this remote snow-covered part of Asia, we focus on 5 receptor locations (shown in Fig. 1), each one model grid box in size, ie. $2 \times 2.5^{\circ}$, and chosen due to the availability of observational data from the glacier sites mentioned above. These regions represent five glaciers where $\mathrm{BC}$ deposition (dry and wet) impacts snow albedo, potentially accelerating snow melt (Flanner et al., 2009; Ramanathan and Carmichael, 2008). Together the five sites are influenced by distinct transport pathways by which BC reaches the Himalayas and Tibetan Plateau (Ming et al., 2008, 2009). The sites include a glacier at the foot of Mt. Everest (Everest site), in the eastern, more polluted part of the Himalayas; Mt. Muztagh glacier (NW Tibetan Plateau) representing flow not affected by the monsoon circulation and located on the western edge of the Tibetan Plateau (Xu et al., 2006); Zuoqiupu glacier (SE Tibetan Plateau), which has experienced a 3.5 fold increase in deposited BC from 1998 to 2005 (Xu et al., 2009a); Meikuang glacier (NE Tibetean Plateau) with very high, partially local, deposition of $\mathrm{BC}$ and 

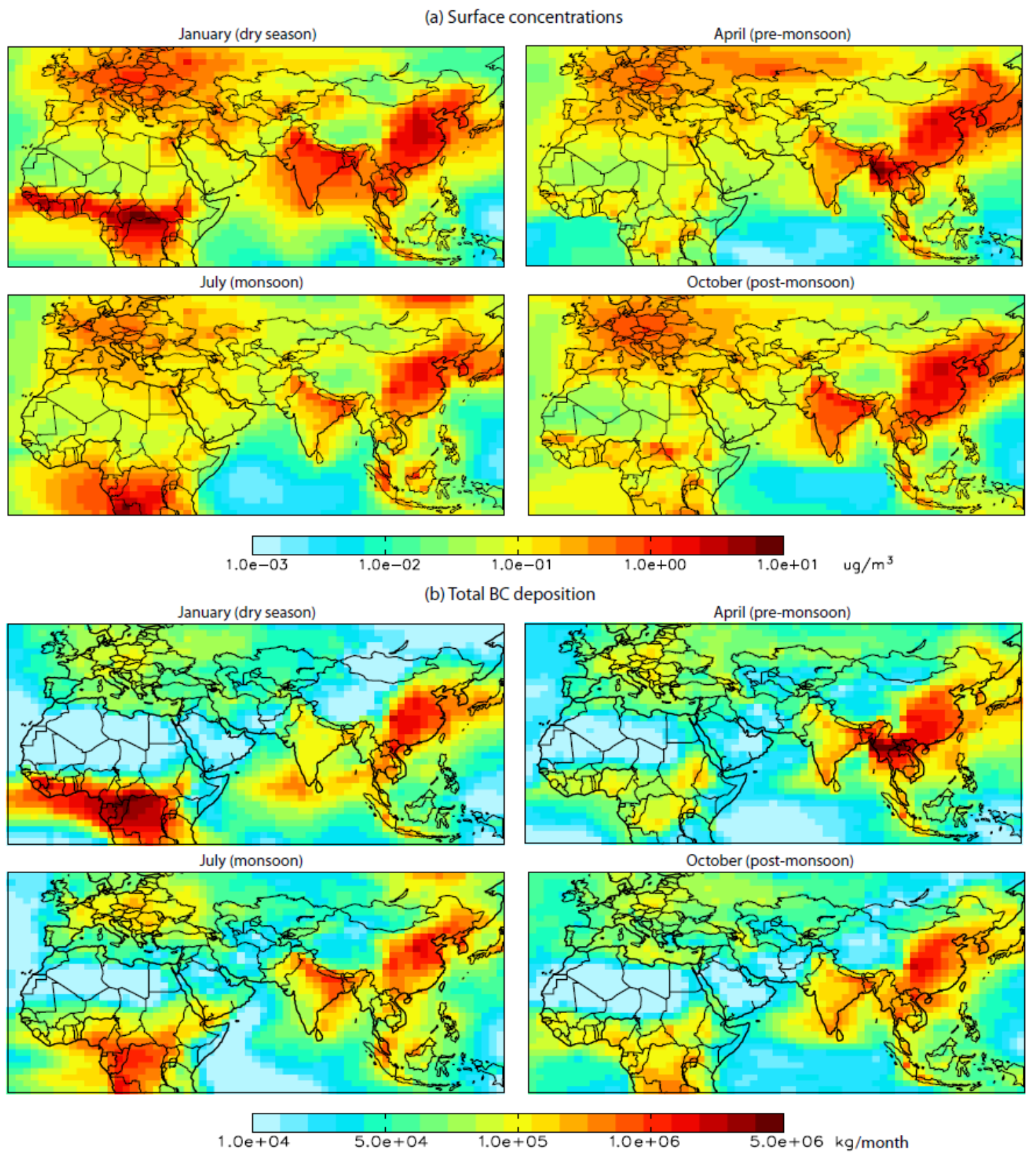

Fig. 2. Seasonal (January, April, July and October monthly means) (a) BC surface concentrations and (b) BC deposition.

potential influence from China to its east; and Miao'ergou glacier (center northern Tibetan Plateau), not on the Tibetan Plateau itself, and thus an extension to Asian glaciers beyond the Third Pole.

We sample the eastern Himalayas with a model grid box that contains East Rongbuk glacier (which starts from Mt. Everest or Qomolangma Peak, $28^{\circ} \mathrm{N}, 89^{\circ} \mathrm{E}$, in the same model grid box). Several BC observations are available in the Himalayas (see Table 1). Comparison of GEOS-Chem simulated BC with available BC concentrations in snow indicates a mix of good agreement (during summer in the east), model underestimate (during summer in the east) and overestimate (during the post-monsoon season in the east and during summer in the west), with observed concentrations generally decreasing from west to east. Both model and measurements find lower BC deposition in the Mt. Everest grid box during the monsoon season than at other times of year. Figure 2 shows that air concentrations are also lower during the monsoon season and recent surface air measurements confirm that seasonality (Marinoni et al., 2010). 


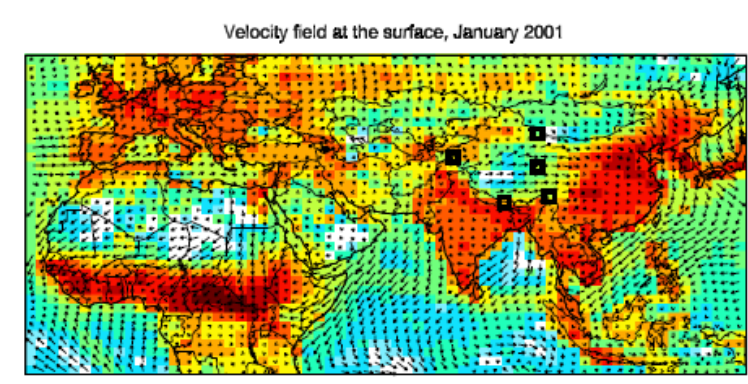

Velocity fiold at the surface, July 2001

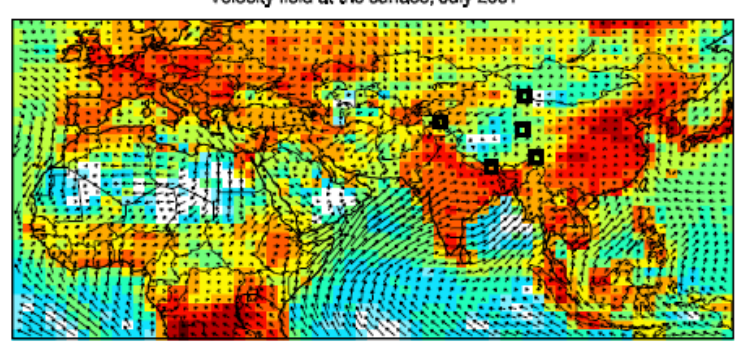

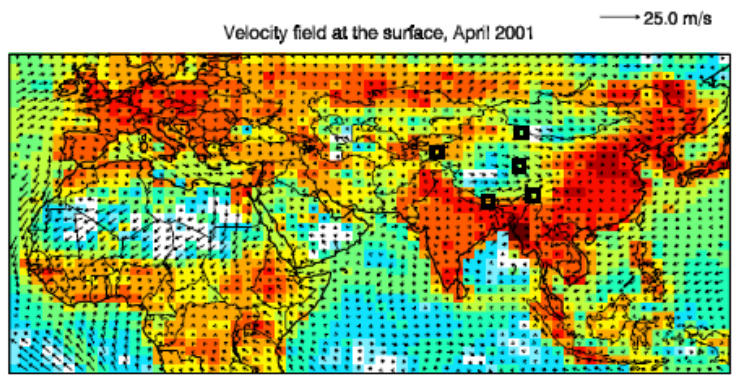

Velocity field at the surface, October 2001

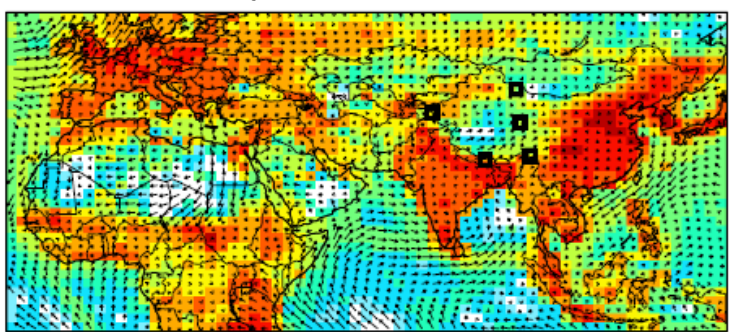

$\begin{array}{lllllll}1.0 \Theta+03 & 1.0 \Theta+04 & 1.0 \theta+05 & 1.0 e+06 & 1.0 \theta+07 & 1.0 \theta+09 & \mathrm{ug} / \mathrm{m}^{\mathrm{e}} / \mathrm{s}\end{array}$

Velocity field at $550 \mathrm{hPa}$, January 2001

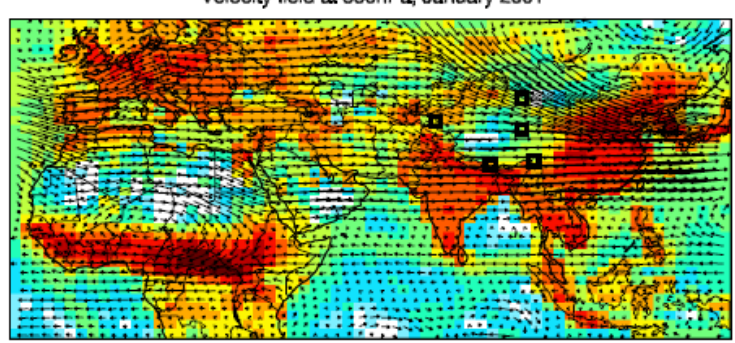

Velocity field at $550 \mathrm{hPa}$, July 2001
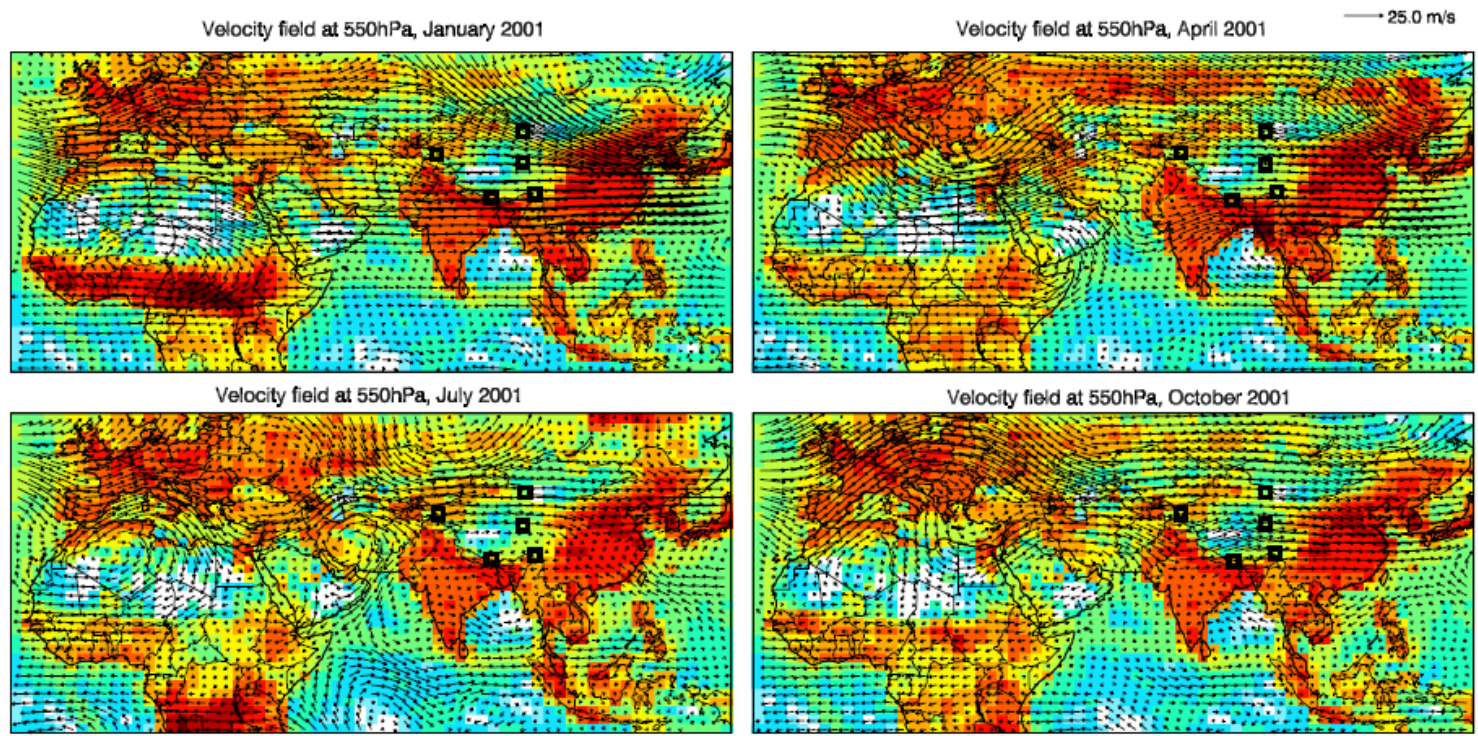

Velocity field at $550 \mathrm{hPa}$, October 2001

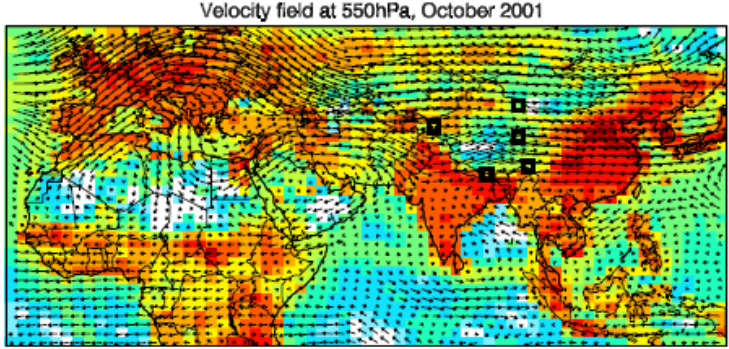

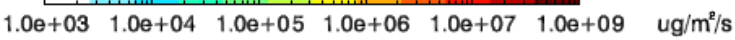

Fig. 3. Horizontal velocity fields at the surface and at 550hPa for January, April, July and October. Each plot represents an average of the first two weeks of the month, corresponding to the period used to calculate the origin of BC reaching the glaciers. Emissions of BC are overlaid in color and include seasonally varying emissions from biomass burning. Glacier sites considered here are marked with black squares.

We sample the southeastern Tibetan Plateau with a model grid box that contains Zuoqiupu glacier $\left(29^{\circ} \mathrm{N}, 97^{\circ} \mathrm{E}\right)$. The limited model comparison with available data indicates a model overestimate of deposition in the region by a factor of 2 during the monsoon and a factor of 4 during non-monsoon seasons. In 2001, the ice core concentrations were $5.1 \mu \mathrm{g} \mathrm{kg}^{-1}$ and $11.3 \mu \mathrm{g} \mathrm{kg}^{-1}$ during monsoon and non-monsoon seasons, while the model estimate was $13.3 \mu \mathrm{g} \mathrm{kg}^{-1}$ and $46.3 \mu \mathrm{g} \mathrm{kg}^{-1}$ respectively. The model does capture the observed factor of 2-3 increase in snow concen- tration from the monsoon to non-monsoon season. Measurements spanning 1998 to 2005 indicate that BC deposited in Zuoqiupu glacier has increased by a factor of 3.5 during that time (Xu et al., 2009a). However, by 2005, observed BC snow concentrations are still lower than the modeled ones: a factor of two lower during non-monsoon season and a third lower during the monsoon. Since the emission inventory used here (Bond et al., 2004) is intended to represent the mid-1990s, this mismatch could result from errors in model transport and precipitation more than emissions. 
Table 1. Sites we focus on later in the paper are identified with an $*$ in the first column.

\begin{tabular}{|c|c|c|c|c|c|c|c|c|c|c|}
\hline \multirow[b]{2}{*}{ \# } & \multirow[b]{2}{*}{ Location name } & \multicolumn{2}{|c|}{ Location } & \multirow[b]{2}{*}{ Elevation (m) } & \multicolumn{2}{|r|}{ Date } & \multirow{2}{*}{$\begin{array}{l}\text { Elev. } \\
\text { (m) }\end{array}$} & \multirow{2}{*}{$\begin{array}{l}\text { Measured } \\
\text { BC conc. } \\
\left(\mu \mathrm{g} \mathrm{kg}^{-1}\right)\end{array}$} & \multirow{2}{*}{$\begin{array}{l}\text { Simulated } \\
\text { BC conc. } \\
\left(\mu \mathrm{g} \mathrm{kg}^{-1}\right)\end{array}$} & \multirow[b]{2}{*}{ reference } \\
\hline & & Lat & Lon & & year & month & & & & \\
\hline \multicolumn{11}{|c|}{ Himalayas } \\
\hline $1^{*}$ & $\begin{array}{l}\text { East Rongbuk } \\
\text { (at the foot of) } \\
\text { Mt. Everest }\end{array}$ & 28.0 & 87.0 & 6465 & 2004 & 10 & 6465 & 18 & 46.0 & Ming et al.( 2009) \\
\hline 2 & ERIC2002C & 28.0 & 87.0 & 6500 & 2002 & summer & 6500 & 20.3 & 22.7 & Ming et al.(2009) \\
\hline 3 & Kangwure & 28.5 & 85.8 & 6000 & 2001 & summer & 6000 & 21.8 & 26.6 & Xu et al. (2006) \\
\hline 4 & Namunani & 30.5 & 81.3 & 6080 & 2001 & summer & 6080 & $0.3-9.7$ & 25.3 & Xu et al. (2006) \\
\hline 5 & Qiangyong & 28.3 & 90.3 & 5400 & 2001 & summer & 5400 & 43.1 & 19.8 & Xu et al. (2006) \\
\hline \multicolumn{11}{|c|}{ Tibetan Plateau } \\
\hline $1 *$ & Zuoqiupu & 29.2 & 96.9 & 5600 & $1998-$ & monsoon & 5500 & $3.3-10.3$ & 13.3 & Xu et al. (2009) \\
\hline & & & & & 2005 & non-monsoon & & $5.3-20.8$ & 43.6 & \\
\hline 2 & La'nong & 30.4 & 90.6 & 5850 & 2005 & 7 & 5850 & 67.3 & 15.0 & Ming et al. (2009) \\
\hline 3 & Qiyi & 39.2 & 97.1 & 4850 & 2005 & 7 & 4850 & 22.5 & 89.7 & Ming et al. (2009) \\
\hline 4 & Zhadang & 30.4 & 90.5 & 5800 & 2006 & 7 & 5800 & 87.4 & 15.0 & Ming et al. (2009) \\
\hline 5 & Laohugou No. 12 & 39.4 & 96.6 & 5045 & 2005 & 10 & 5045 & 35.5 & 129 & Ming et al. (2009) \\
\hline 6 & July 1 glacier & 39.0 & 98.0 & 4600 & 2001 & summer & 4600 & $29-75.9$ & 61.2 & $\mathrm{Xu}$ et al. (2006) \\
\hline $7 *$ & Meikuang & 36.0 & 94.0 & 5200 & 2001 & summer & 5200 & 446 & 26.7 & Xu et al. (2006) \\
\hline 8 & Dongkemadi & 33.0 & 92.0 & 5600 & 2001 & summer & 5600 & 18.2 & 15.1 & Xu et al. (2006) \\
\hline $9 *$ & Mt. Muztagh & 38.3 & 75.0 & 6350 & 2001 & summer & 6350 & 37.2 & 16.7 & Xu et al. (2006) \\
\hline \multicolumn{11}{|c|}{ North of Tibetan Plateau } \\
\hline 1 & Haxilegen River & 43.7 & 84.5 & 3755 & 2006 & 10 & 3755 & 46.9 & 39.4 & Ming et al. (2009) \\
\hline \multicolumn{11}{|c|}{ No. 48} \\
\hline $2 *$ & Miao'ergou No. 3 & 43.1 & 94.3 & 4510 & 2005 & 8 & 4510 & 111 & 94.5 & Ming et al. (2009) \\
\hline
\end{tabular}

We examine a region in the northeastern Tibetan Plateau with a model grid box that contains the Meikuang glacier $\left(36^{\circ} \mathrm{N}, 94^{\circ} \mathrm{E}\right)$. We chose this site due to the large BC concentrations in surface snow reported by $\mathrm{Xu}$ et al. (2006), $446 \mu \mathrm{gg}^{-1}$, and due to its location: the central-northeastern Tibetan Plateau, near the origin of the Yellow and Yangtze rivers which could potentially be affected by glacier melt. $\mathrm{Xu}$ et al. (2006) report the possibility of nearby coal containing rock strata contributing $\mathrm{BC}$ to the Meikuang site. Similarly, relatively high concentrations near major population centers on the Plateau at Zhadang and La'nong glaciers $\left(87.4 \mu \mathrm{g} \mathrm{kg}^{-1}\right.$ and $\left.67.3 \mu \mathrm{g} \mathrm{kg}^{-1}\right)$ are not captured by the model $\left(15.0 \mu \mathrm{g} \mathrm{kg}^{-1}\right.$ and $\left.15.0 \mu \mathrm{g} \mathrm{kg}^{-1}\right)$. Modelmeasurement comparison at a nearby glacier confirms that Meikuang, Zhadang and La'nong concentrations are unusually large (Table 1). The concentration at nearby Dongkemati glacier is $18.2 \mu \mathrm{g} \mathrm{kg}^{-1}\left(15.1 \mu \mathrm{g} \mathrm{kg}^{-1}\right.$ in the model). This concentration difference highlights an important question of the role of local versus distant contributions to BC in the air above and to the snow of the glaciers. Complicating the picture are several model uncertainties, including model transport in a topographically complex region, potential inaccuracies in emission inventories, uncertainties in precipitation frequency, amount and location, as well as BC aging. However, given the model's ability to represent $\mathrm{BC}$ concentrations that are not influenced by local sources, it appears likely that the model also represents background concentrations successfully (Park et al., 2005).

We examine a region of the western Tibetan Plateau using a model grid box that contains the Mt. Muztagh glacier in the Pamir Range $\left(38^{\circ} \mathrm{N}, 75^{\circ} \mathrm{E}\right)$. The model comparison with available surface snow concentrations is complicated, since the measured snow most likely underwent aging. The $37.2 \mu \mathrm{g} \mathrm{kg}^{-1}$ measured during the summer is larger than the $16.7 \mu \mathrm{g} \mathrm{kg}^{-1}$ simulated by the model. The seasonal cycle of $\mathrm{BC}$ in the model is consistent with observations of the seasonal cycle at other sites (Xu et al., 2006), and indicates concentrations during the summer that are half as large as those in other seasons.

In addition to the sites strictly in the Himalayas and the Tibetan Plateau, we also select the Miao'ergou glacier $\left(43^{\circ} \mathrm{N}\right.$, $\left.94^{\circ} \mathrm{E}\right)$ site north of the Tibetan Plateau, in the Tienshan Mountains (Ming et al., 2009). This site has been found to contain some of the largest amounts of BC in the Asian glaciers and it is hypothesized that European emissions contribute significantly (Ming et al., 2009). In addition, examining this site and region allows us to assess to what extent the Asian glaciers outside the Tibetan Plateau are impacted by global BC emissions. Simulated BC concentrations in snow are within $15 \%$ of the observations at the site, and at $94.5 \mu \mathrm{g} \mathrm{kg}^{-1}$ are the second highest of the sites studied. 


\section{Radiative forcing due to $\mathrm{BC}$ in the Third Pole}

We compute radiative forcing of $\mathrm{BC}$ resulting from its direct and snow albedo effects. Following recent studies (Kopp and Mauzerall (2010) and referenced studies therein), we approximate the impact of non-resolved internal mixing of aerosols by multiplying the direct $\mathrm{RF}$ of $\mathrm{BC}$ by 1.5 . For both effects, we use the RTM described in Sect. 2 and our GEOS-Chem derived albedo changes. Our global annual mean direct (external mixing only) forcing is $+0.36 \mathrm{~W} \mathrm{~m}^{-2}$ for clear-sky and $+0.16 \mathrm{~W} \mathrm{~m}^{-2}$ for the all-sky condition (after multiplying by cloud fraction). Correcting for internal mixing of $\mathrm{BC}$, this yields $+0.54 \mathrm{~W} \mathrm{~m}^{-2}$ and $+0.24 \mathrm{~W} \mathrm{~m}^{-2}$, respectively. The estimate with all-sky and internal mixing adjustments, $+0.24 \mathrm{~W} \mathrm{~m}^{-2}$, is in agreement with the latest AeroCom's average of $+0.25 \mathrm{~W} \mathrm{~m}^{-2}$ (Koch et al., 2009b) and slightly higher than the recent meta-analysis estimate of $+0.22 \mathrm{~W} \mathrm{~m}^{-2}$ (Kopp and Mauzerall, 2010). Although this comparison is encouraging, each study included different treatment of indirect and snow albedo effects, as well as internal/external mixing of aerosols. To compute monthly mean snow albedo change due to $\mathrm{BC}$ deposition we use the quantities of BC deposited in our GEOS-Chem simulations with a previously established relationship between $\mathrm{BC}$ mass fraction in snow and ice and a spectrally averaged change in snow albedo (Ming et al., 2009). A similar relationship was previously employed by Hansen and Nazarenko (2004) and Koch et al. (2009a). We compute BC mass fraction as the ratio of total deposited BC (wet and dry deposition) to total precipitation. We thus neglect snow aging or particle accumulation during snow melting. Meanwhile, aging of snow alone, unaffected by aerosol deposition, can result in a change in albedo of up to 0.12 after two weeks (Flanner and Zender, 2006). In addition, Xu et al. (2006) observed that while BC concentrations in fresh snow average $6.6 \mu \mathrm{g} \mathrm{kg}^{-1}$ for a particular site, after two days of surface melting they increased and measured $52.6 \mu \mathrm{g} \mathrm{kg}^{-1}$. Thus our assumptions likely underestimate the snow albedo effect.

Figure 4 shows the seasonal cycle of instantaneous radiative forcing due to $\mathrm{BC}$ direct and snow-albedo effects in five model grid boxes containing the five glacier sites. Although we report both forcing numbers for each grid box examined, the calculated snow albedo forcing is not necessarily uniform over the entire grid box. Rather, it is representative of the snow covered areas within the grid box. The five sites we consider in this study correspond to glaciers and hence are snow-covered year round. The clear-sky direct radiative forcing due to $\mathrm{BC}$ for all glacier sites is typically about +0.5 $\pm 1.0 \mathrm{~W} \mathrm{~m}^{-2}$ before it is adjusted for internal mixing, and $+0.75-+1.5 \mathrm{~W} \mathrm{~m}^{-2}$ after. The corresponding full range of the direct forcing is +0.19 to $+1.74 \mathrm{~W} \mathrm{~m}^{-2}$ before the internal mixing adjustment, and +0.29 to $+2.61 \mathrm{~W} \mathrm{~m}^{-2}$, after the adjustment.

Radiative forcing due to snow albedo change is much larger and ranges from +3.78 to $+15.6 \mathrm{~W} \mathrm{~m}^{-2}$, with low-

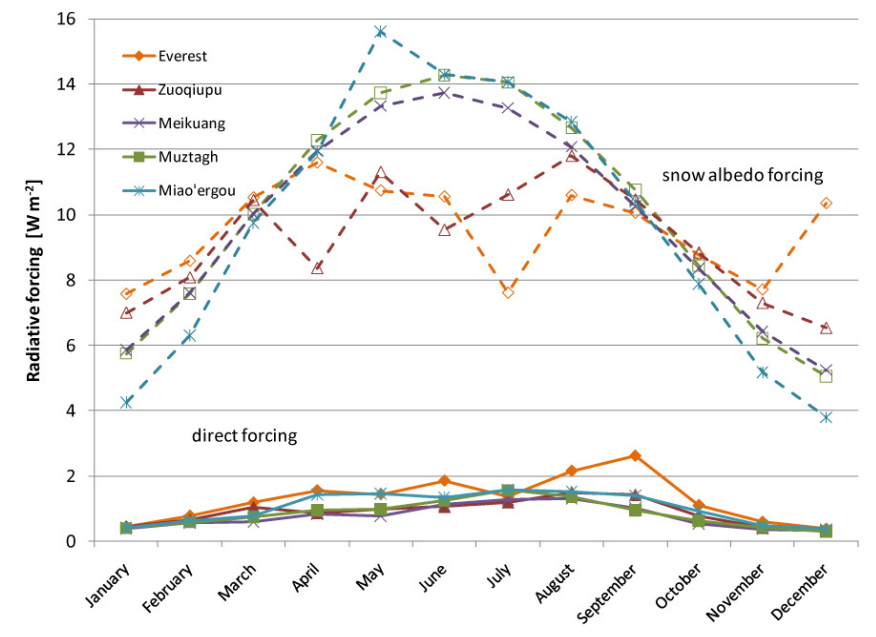

Fig. 4. Monthly mean radiative forcing due to direct (solid lines) and snow albedo effect (dashed lines) at the five glacier sites in the Himalayas and the Tibetan Plateau we analyze as receptors: Mt. Everest (Himalayas), Zuoqiupu glacier (southeastern Tibetan Plateau), Meikuang (northeastern Tibetan Plateau), Mt. Muztagh (western Tibetan Plateau), and Miao'ergou (north of Tibetan Plateau). Direct effect forcing is a clear-sky estimate corrected for internal mixing.

est and highest values found at the northernmost site during winter and summer, respectively. Lower latitude sites of Mt. Everest and Zuoqiupu exhibit a weaker seasonal cycle. Meanwhile, our calculations of snow albedo change alone do not exhibit significant seasonality with most values around $6 \%$ throughout the year. We thus conclude that the seasonality in radiative forcing is due largely to the seasonal changes in solar irradiance. While expected at high latitudes of the Arctic, we also find a strong seasonal signal at $30^{\circ}-35^{\circ} \mathrm{N}$. This seasonality has potential consequences for increased snow melt. Our high radiative forcing values in summer suggest an increased rate of glacier and high altitude melting in summer due to BC deposition and potentially a melting season that extends into spring and fall. Thus in order to reduce glacial melting, it might be as crucial to focus on summer emissions as on other seasons. However, formal calculations of the connection between radiative forcing and snow melt are beyond the scope of this study. In conclusion, while we do not assess the climatic impact of the radiative forcing here, our calculations suggest that in the snow-covered areas in the Third Pole the snow-albedo effect clearly dominates the direct radiative forcing signal and likely enhances glacial melting rates.

Our radiative forcing numbers, especially for the snow albedo effect, are consistent with results of previous studies. Flanner et al. (2007) estimates up to $+20 \mathrm{~W} \mathrm{~m}^{-2}$ radiative forcing from the snow-albedo effect in the Tibetan Plateau during the spring, and Ming et al. (2008) report $+4.5 \mathrm{~W} \mathrm{~m}^{-2}$ in the eastern Himalayas during the summer, which are both 
within the range of our estimates. The values for radiative forcing due to the $\mathrm{BC}$ direct effect are more varied. Over India, Menon et al. (2010) find $+0.85 \mathrm{~W} \mathrm{~m}^{-2}$ using the same Bond et al. (2004) emissions, and $+1.37 \mathrm{~W} \mathrm{~m}^{-2}$ using Beig emissions inventory (Sahu et al., 2008). Our values are only for the remote glacier regions and are not directly comparable. In fact, typically global model studies only report globally averaged radiative forcing (Hansen and Nazarenko, 2004), masking regional variability and locations of high or low RF, especially in snow covered regions due to the snowalbedo effect.

\section{Origin of $\mathrm{BC}$ at the Third Pole}

The origin of $\mathrm{BC}$ at the Third Pole is inadequately understood. Estimating the origin of BC (both source location and magnitude) at the Third Pole is of great scientific and policy importance as the region provides water for a large proportion of the Asian population. Of societal importance is the warming due to $\mathrm{BC}$ that will accelerate glacier melting, thus affecting water resources. This is the first study that attempts to identify the magnitude of contributions from different BC source regions to the Third Pole. Our analysis indicates where future emission reductions might be most helpful in slowing warming and glacier melt. As a first step, we use the GEOS-Chem adjoint model to identify the source regions contributing $\mathrm{BC}$ transported to the atmospheric column above five glaciers. The adjoint approach allows for much greater computational efficiency than the forward model approach (Ramanathan and Carmichael, 2008). Also, unlike a back trajectory approach (Ming et al., 2009), which only tracks air mass flow to the receptor site, the adjoint calculates the quantity of $\mathrm{BC}$ contributed to the receptor site from emissions in each grid box in the global model.

The most striking result of our study is the spatial extent of $\mathrm{BC}$ source regions that impact the Third Pole and how the contribution of those source regions varies seasonally. Meanwhile, there is no seasonal variability in $\mathrm{BC}$ emission inventories, except for biomass burning. Figure 5 shows the locations from which BC that reaches the air above (and partly deposits on) the five glaciers shown in Fig. 1 originates in each season. The dominant sources change with season and vary with receptor location within the Third Pole. However, the overwhelming majority of $\mathrm{BC}$ that is transported to the Third Pole is emitted in India and China, with substantial seasonal contributions from Nepal and the Middle East. The GEOS-Chem adjoint model indicates that 3-4 times as much BC is transported to the atmospheric column above the Mt. Everest receptor grid box as at the sites in the Tibetan Plateau. However, the observed BC mass fraction in the Everest grid box tends to be less than in the Tibetan Plateau, due to much larger precipitation, and the model generally overestimates that deposition fraction. The
Miao'ergou site atmospheric column, for example, receives about half as much $\mathrm{BC}$ as the Everest grid box, although the relative concentration of $\mathrm{BC}$ in snow (BC mass fraction) at that site is about a factor of five larger, resulting from lower precipitation at Miao'ergou than at Everest.

Detailed maps of the origin of BC transported to each air column (Fig. 5) reveal emission hot spots and substantial seasonal variations. The maps show sensitivity of $\mathrm{BC}$ in the air column above each glacier and at the glacier surface to emissions from all grid boxes. In short, they are emission contributions, the $\mathbf{K} \mathbf{x}$ quantity in Eq. (1). Hence, the flux units are $\mu \mathrm{km}^{-2} \mathrm{day}^{-1}$. In Table 2 we quantify seasonal and annual average country level contributions to each glacier grid box, but note that regional and seasonal variation within countries is important and can be seen in the figures. The numbers are subject to numerous uncertainties and should be used only for a qualitative assessment of the relative importance of regional $\mathrm{BC}$ contributions to each receptor site. Our results underscore not only potential locations to prioritize emission reductions, but also the need for reducing emission inventory uncertainties.

\subsection{Origin of $\mathrm{BC}$ reaching the Himalayas (East Rongbuk glacier)}

Figure 3 shows the variability in $\mathrm{BC}$ emissions seasonally with wind magnitude and direction at the surface and at $500 \mathrm{mb}$ overlaid. Our simulations indicate that emissions from India, China and Nepal deliver about $91 \%$ of BC in the atmospheric column at the Everest site, on average about 15, 12 and 10 tonnes per day respectively. Throughout the year, the attribution of local and regional Himalayan emissions to a particular country is difficult due to the coarse resolution of the model. The Himalayas span at most two grid boxes in the north-south direction, about ten grid boxes in the west-east direction, and cut across India, Nepal and China. The contributions also exhibit significant seasonal and geographical variability. In January, BC comes from the regions immediately adjacent to the Himalayas and southern Tibetan Plateau. The mid-tropospheric flow also transports BC from African biomass burning. January biomass burning in Africa emits large amounts of BC, which typically do not result in warming (Kopp and Mauzerall, 2010), but the fraction that travels to snow covered regions can result in significant warming due to its effect on snow albedo. Thus the contribution of approximately 1 tonne of BC per day from tropical northern Africa is significant, especially as nearby emissions from Pakistan only contribute a third of that in January. In April, BC comes mostly from India and Nepal (30 and 17 tonnes per day on average) and to smaller extent from south-western China (12 tonnes per day on average). In July, the monsoon flow near the surface brings BC from across southern and southeastern India and through the Bay of Bengal (13 tonnes per day) and from southeastern China (15 tonnes per day). 
(a) Everest (Himalayas)
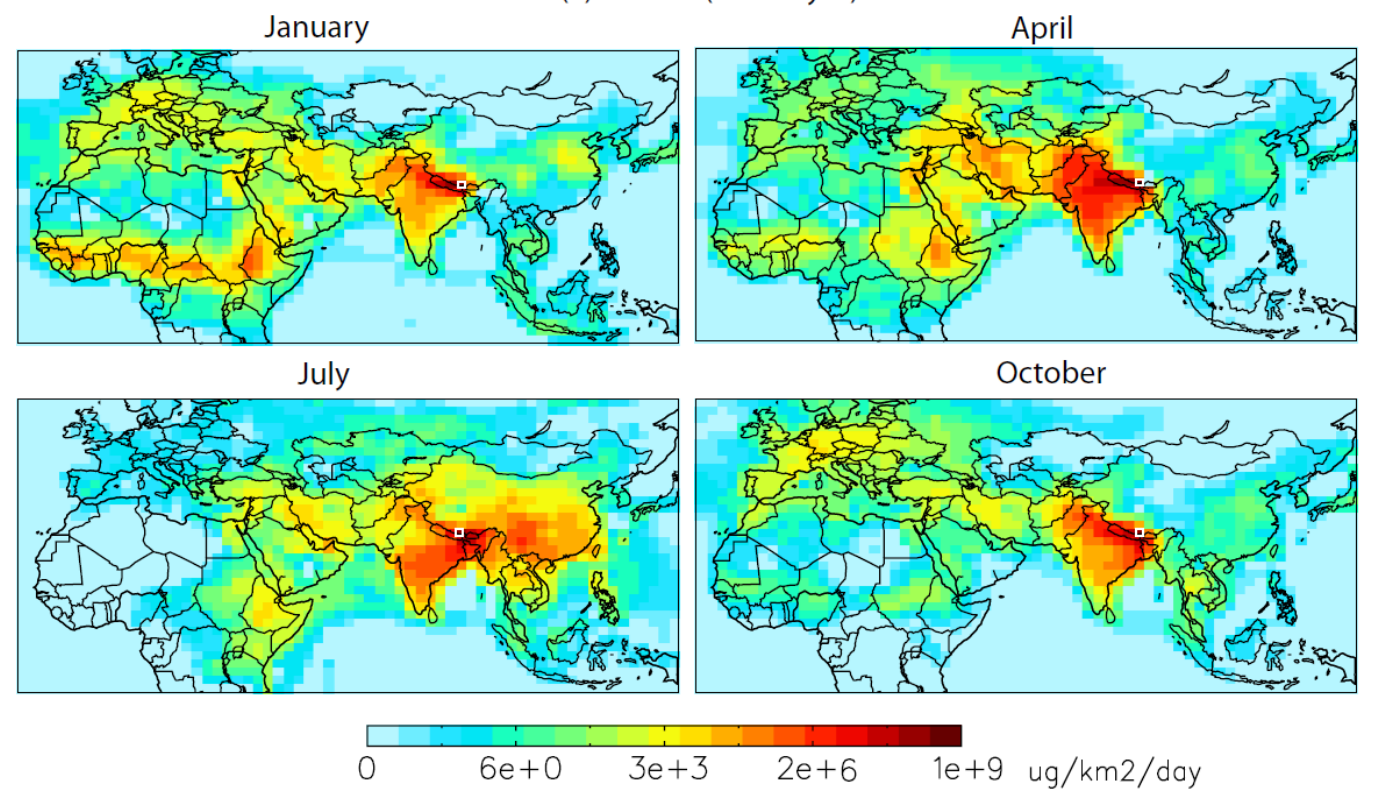

(b) Zuoqiupu (southeastern Tibetan Plateau)
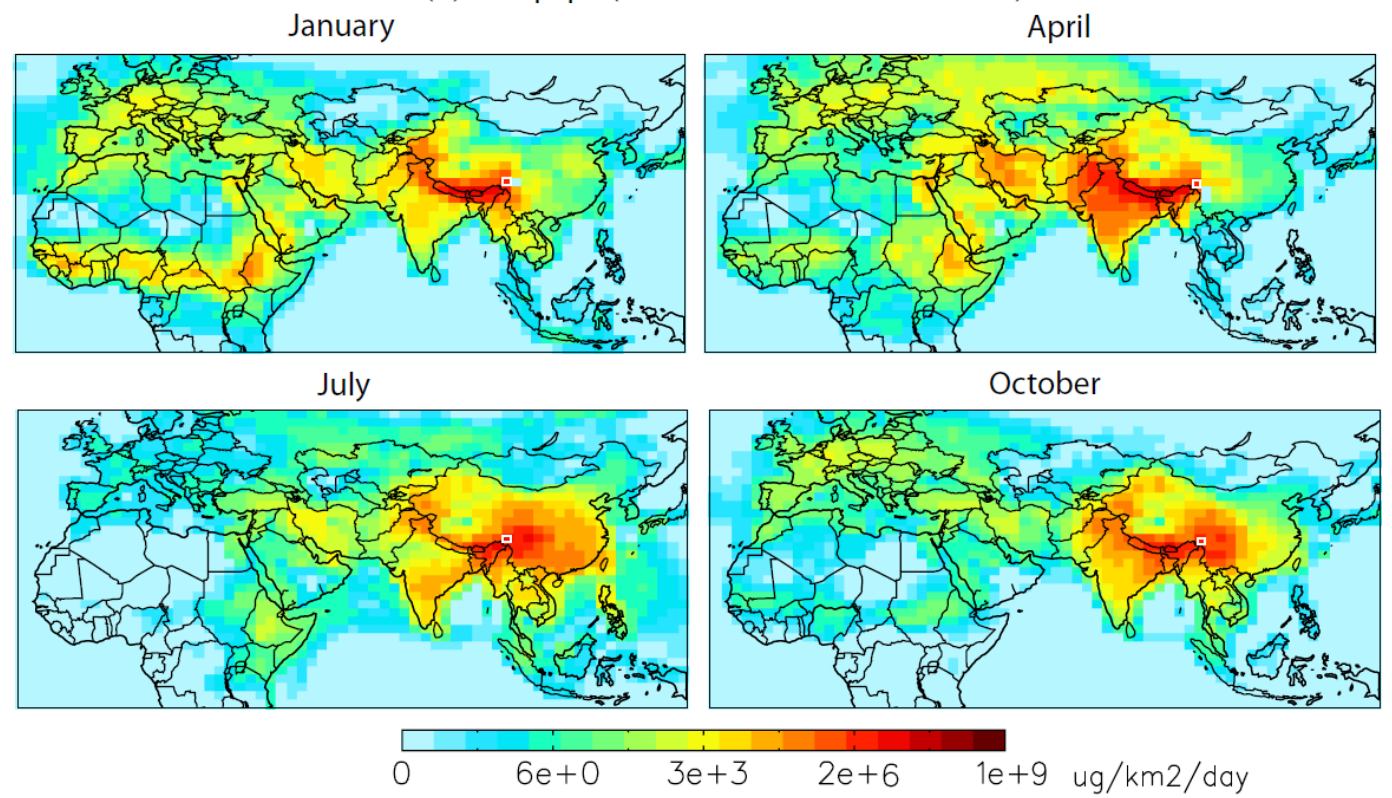

Fig. 5. Origin of black carbon by season (January, April, July, October) at five glacier sites throughout the Third Pole (a) Mt. Everest (Himalayas), (b) Zuoqiupu glacier (southeastern Tibetan Plateau), (c) Meikuang (northeastern Tibetan Plateau), (d) Mt. Muztagh (western Tibetan Plateau), and (e) Miao'ergou (north of Tibetan Plateau). The grid box containing each glacier site is outlined in white. The quantity of $\mathrm{BC}$ arriving at each glacier grid box from each grid box in the domain is indicated in color.

Together India and China contribute about $75 \%$ of monsoon $\mathrm{BC}$ transported to the Everest grid box. During the postmonsoon seasons (October), the majority of $\mathrm{BC}$ in the atmospheric column over the Everest grid box comes from nearby locations in China, Nepal and India's Ganges Valley, similarly to the pre-monsoon season (April).

\subsection{Origin of $\mathrm{BC}$ reaching the southeastern Tibetan Plateau (Zuoqiupu glacier)}

Wind patterns (Fig. 3) and emission contributions (Fig. 5) at Zuoqiupu are qualitatively similar to those at Mt. Everest during the first half of the year and exhibit strong seasonality. In January, most BC comes from the Himalayas and southern 
(c) Meikuang (Tibetan Plateau)
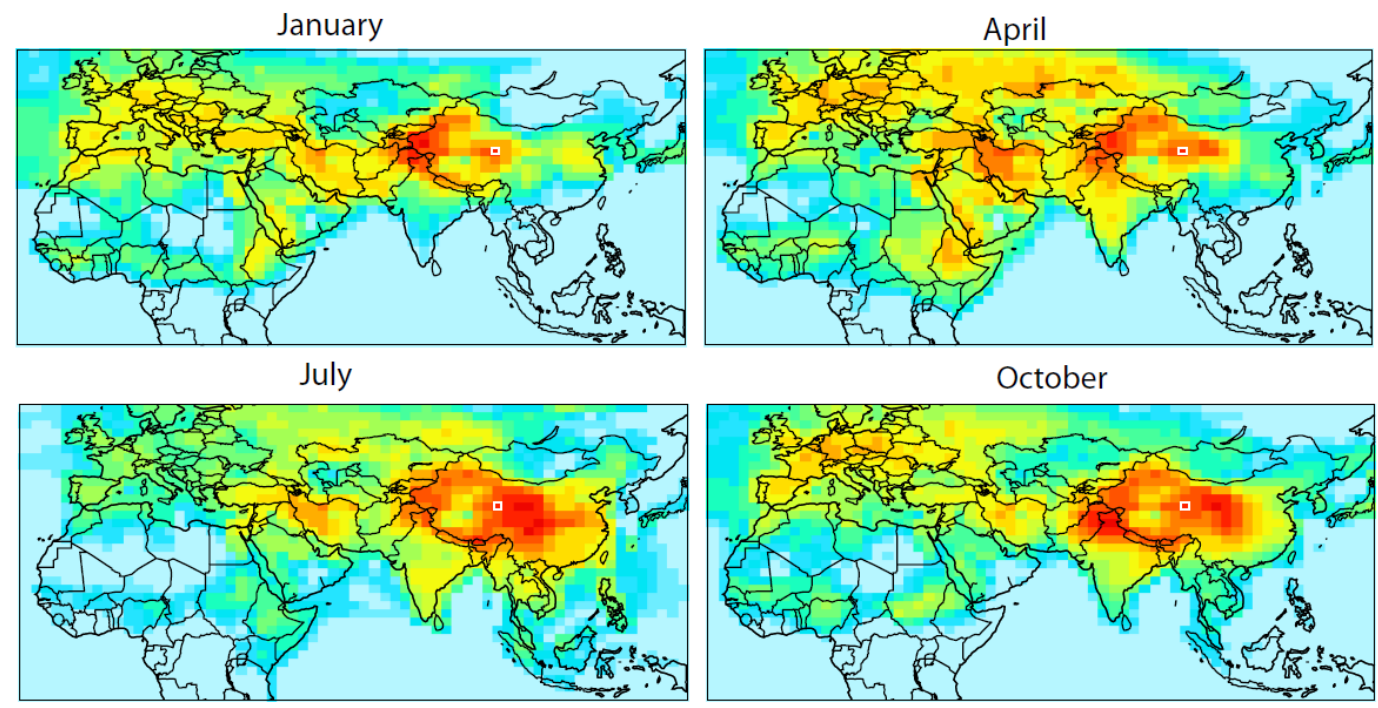

$\begin{array}{lllll}6 e+0 & 3 e+3 & 2 e+6 & 1 e+9 & \mathrm{ug} / \mathrm{km} 2 / \mathrm{day}\end{array}$

(d) Mt. Muztagh (Tibetan Plateau)
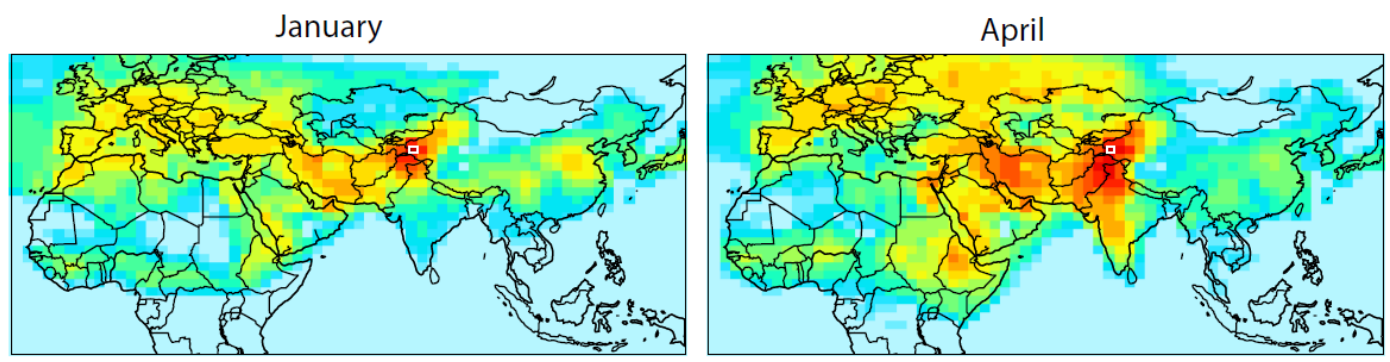

July

October
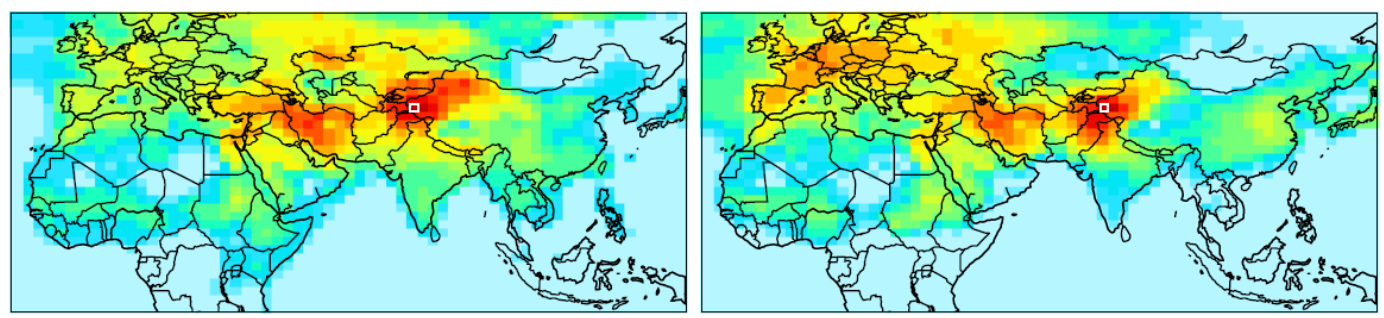

$0 \quad 6 e+0 \quad 3 e+3 \quad 2 e+6 \quad 1 e+9 \quad \mathrm{ug} / \mathrm{km} 2 /$ day

Fig. 5. Continued.

Tibetan Plateau. The mid-tropospheric flow also brings BC from African biomass burning and the Middle East. In April, emissions from India make up half of the $\mathrm{BC}$ arriving at Zuoqiupu. During the monsoon season (in July), the Zuoqiupu grid box is under the influence of mid-tropospheric flow from south-eastern China in the east, while in October the boundary layer flow again allows for transport from southeastern China, rather than India. Thus, in July and October, south-eastern Chinese emissions dominate in the Zuoqiupu grid box; other regions are relatively unimportant. On an annual mean basis, Zuoqiupu grid box receives emissions mainly from China and India (about 5 tonnes of emissions per day from each), with smaller contributions from Nepal (1.3 tonnes), Bhutan (0.7 tonnes) and Pakistan (0.6 tonnes). The much lower quantities of $\mathrm{BC}$ reaching Zuoqiupu than Everest, the similarity of sources for the two sites, and the 
(e) Miao'ergou
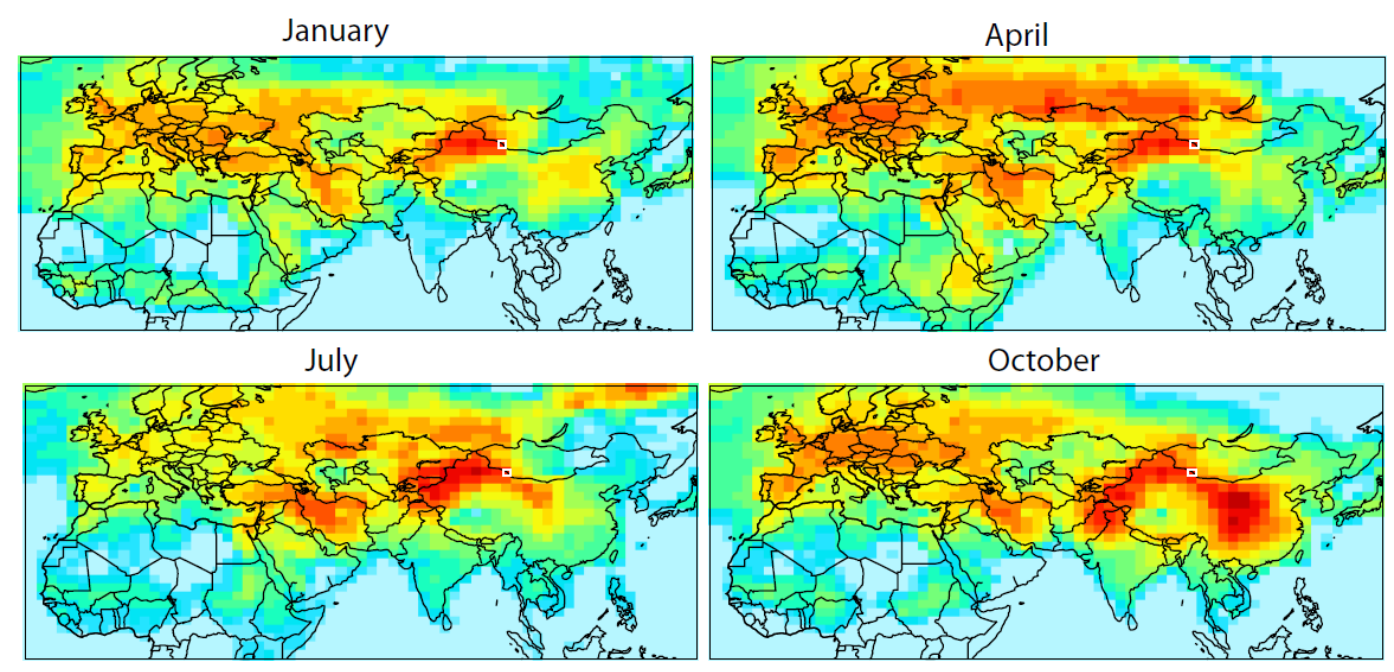

$\begin{array}{llllll}0 & 6 e+0 & 3 e+3 & 2 e+6 & 1 e+9 & u g\end{array}$

Fig. 5. Continued.

model overestimation of BC concentrations in snow at Zuoqiupu together further support our conclusion that the differences in model-data agreement at those two sites are due to transport and/or precipitation.

\subsection{Origin of $\mathrm{BC}$ reaching the northeastern Tibetan Plateau (Meikuang glacier)}

As shown in Table 2 and Fig. 5c, our model results indicate that the primary contribution of $\mathrm{BC}$ to the Meikuang glacier is from long-range transport of western Chinese emissions, which during the first half of the year are carried by midtropospheric westerlies, while during July and October are primarily due to boundary layer flow from central-eastern China. Overall in the Meikuang grid box, emissions from China are responsible for approximately 7.6 tonnes of $\mathrm{BC}$ per day, emissions from Pakistan are about half that at 3.2 tonnes per day and contributions from India are 1.3 tonnes per day. Emissions from Pakistan arrive at Meikuang throughout the year, while Indian emissions are mostly transported in October from the northernmost part of the country via high altitude flow. There is a strong seasonality in transport, as the Meikuang region receives three times more $\mathrm{BC}$ pollution during July and October than during January and April. Since in our simulation emissions in the region do not vary seasonally (except for biomass burning), this is mostly due to changing meteorology. In particular, as seen in Fig. 5c, the westerly contributions from relatively small source regions (Middle East and northwestern China) to the west dominate in the first half of the year, while large sources from industrial eastern China dominate contributions during the second half of the year.

\subsection{Origin of $\mathrm{BC}$ reaching the western Tibetan Plateau (Mt. Muztagh glacier)}

The adjoint simulation indicates that the majority of $\mathrm{BC}$ that arrives at Mt. Muztagh is from nearby regions of western China, Kyrgyzstan, Tajikistan and Pakistan, with up to $10 \mu \mathrm{g} \mathrm{km}^{-2}$ day $^{-1}$ from some grid boxes in western China. It is difficult at our resolution to accurately attribute the origin of emissions to a particular country, however. Another significant portion of BC originates in the Middle East (especially Iran via mid-tropospheric flow) and contributes about 1.9 tonnes of BC per day, even though Middle East is not a large absolute emission source according to the emission inventory. In comparison, emissions from China contribute on average 6.9 tonnes per day, while emissions from Pakistan and India contribute about 2.4 and 0.9 tonne per day, respectively. Together, just four countries (China, Iran, India and Pakistan) contribute $76 \%$ of BC at Mt. Muztagh, with $46 \%$ from China alone. Strong seasonality in transport exists. January contributions are about $25 \%$ of the annual total BC influx. In April, the Mt. Muztagh grid box receives BC from Iran, India, Pakistan and China at the rate of 1.5, 2.7, 3.9 and 5 tonnes per day, respectively. Meanwhile, outside of April, Indian emissions make a small contribution (much less than 1 tonne per day), with China, Pakistan and the Middle East contributing the large majority of BC (up to 13 tonnes per day from China in July). Distant European emissions do not contribute in any significant amount, either due to low emissions in the Bond et al. (2004) inventory, meteorological conditions, or both. 
Table 2. National/regional origin of BC reaching the atmospheric column above the grid box containing the glacier sites for each month of simulation and an annual average. Units are kg per country or region per day.

\begin{tabular}{|c|c|c|c|c|c|c|c|c|}
\hline Site & Month & China & India & Pakistan & Nepal & Middle East & Africa & Russia \\
\hline \multirow[t]{5}{*}{ Mt. Everest } & January & 11500 & 6850 & 241 & 10300 & 162 & 923 & 2 \\
\hline & April & 12200 & 29500 & 3200 & 17400 & 954 & 260 & 13 \\
\hline & July & 15000 & 12900 & 79 & 5120 & 95 & 48 & 1 \\
\hline & October & 11000 & 11700 & 486 & 9000 & 74 & 4 & 3 \\
\hline & Annual & 12500 & 15200 & 1000 & 10500 & 321 & 140 & 5 \\
\hline \multirow[t]{5}{*}{ Zuoqiupu } & January & 4620 & 4400 & 131 & 1310 & 117 & 419 & 2 \\
\hline & April & 5890 & 11400 & 1800 & 3460 & 721 & 133 & 49 \\
\hline & July & 7640 & 1990 & 86 & 80 & 38 & 5 & 2 \\
\hline & October & 5210 & 2590 & 213 & 542 & 23 & 2 & 1 \\
\hline & Annual & 5820 & 5100 & 558 & 1350 & 225 & 140 & 13 \\
\hline \multirow[t]{5}{*}{ Meikuang } & January & 3640 & 608 & 532 & 56 & 318 & 18 & 22 \\
\hline & April & 3250 & 336 & 382 & 19 & 926 & 135 & 360 \\
\hline & July & 15160 & 599 & 177 & 87 & 247 & 1 & 46 \\
\hline & October & 8460 & 3520 & 2070 & 325 & 241 & 6 & 43 \\
\hline & Annual & 7600 & 1270 & 791 & 122 & 433 & 40 & 118 \\
\hline \multirow[t]{5}{*}{ Mt. Muztagh } & January & 2490 & 232 & 902 & 1 & 552 & 7 & 19 \\
\hline & April & 5030 & 2740 & 3920 & 6 & 2260 & 175 & 239 \\
\hline & July & 13000 & 151 & 1370 & 5 & 2870 & 3 & 161 \\
\hline & October & 7000 & 640 & 3320 & 0 & 1760 & 6 & 150 \\
\hline & Annual & 6880 & 941 & 2380 & 3 & 1860 & 48 & 142 \\
\hline \multirow[t]{5}{*}{ Miao'ergou } & January & 4540 & 6 & 7 & 0 & 379 & 4 & 493 \\
\hline & April & 4270 & 12 & 38 & 0 & 908 & 49 & 5269 \\
\hline & July & 13400 & 38 & 226 & 1 & 1770 & 2 & 1493 \\
\hline & October & 38800 & 838 & 1570 & 12 & 972 & 1 & 626 \\
\hline & Annual & 15300 & 223 & 459 & 3 & 1000 & 14 & 1970 \\
\hline
\end{tabular}

\subsection{Origin of $\mathrm{BC}$ reaching north of the Tibetan Plateau (Miao'ergou glacier)}

Although the Miao'ergou glacier is not on the Tibetan Plateau, it is affected by some of the same emission regions and meteorological conditions that transport $\mathrm{BC}$ to the other locations we examined. As seen in Table 2 and Figure 5, the adjoint model indicates that emissions from north-western China contribute substantially to this glacier site throughout the year, at the rate of about 4 tonnes per day from some grid boxes, with an annual average contribution from China of about 15.3 tonnes per day. In October, emissions from eastern China dominate with almost 39 tonnes per day arriving from China versus 4.3-13.4 tonnes in other months. During spring, the contribution from Russian biomass burning is comparable to that from China. Due largely to the spring agricultural burning and summer boreal forest burning, Russian biomass burning emissions contribute 5.3 and 1.5 tonnes, respectively, of $\mathrm{BC}$ per day in those seasons. This Russian biomass burning contribution is unique in the glaciers we consider, indicating that while biomass burning emissions from Russia might not reach the Tibetan Plateau, northern Asian glaciers are affected by them. Similarly to the glaciers on the Tibetan Plateau, Miao'ergou is chronically affected by BC from Pakistan and the Middle East, at an average rate of 1.8 and 1 tonne per day, respectively. Indian emissions do not appear to contribute significantly.

\section{Conclusions and discussion}

We employed the GEOS-Chem model and its adjoint to analyze the origin of $\mathrm{BC}$ reaching the Third Pole. We estimated the location and magnitude of emissions that affect five sites located throughout the region. In addition, we computed the radiative forcing due to direct and snow-albedo effects of $\mathrm{BC}$. GEOS-Chem generally represents the spatial and seasonal variation of $\mathrm{BC}$ content in snow at the Third Pole with lower concentrations during the summer monsoon season than during the rest of the year. Both under- and overestimates of simulated BC are found, but with no consistent bias. We attribute at least part of the mismatch to the global model's inability to accurately represent transport and precipitation in this topographically complex region. Our monthly mean 
radiative forcing due to $\mathrm{BC}$ direct effect in the five glacier sites ranges from $+0.39 \mathrm{~W} \mathrm{~m}^{-2}$ to $+3.5 \mathrm{~W} \mathrm{~m}^{-2}$, with a global annual mean of $+0.32 \mathrm{~W} \mathrm{~m}^{-2}$. The local monthly mean radiative forcing due to changes in snow-albedo ranges from +3.78 to $+15.6 \mathrm{~W} \mathrm{~m}^{-2}$.

The most striking result of our study is the seasonal and spatial variation of sources that contribute $\mathrm{BC}$ to the Third Pole glaciers. We identify large comparable emission contributions from northern India, Nepal and south-eastern China to the Himalayas. Large dry season African biomass burning emissions, though far away, are transported and deposited in non-negligible amounts (up to about 1 tonne per day) in the Himalayas. Tibetan Plateau glaciers mostly receive BC emitted in western and central China, the Middle East and to some extent India. All emission contributions vary with season and exact location of the glaciers. Our study thus identified regions from which $\mathrm{BC}$ emissions appear to significantly contribute to warming over the Third Pole and where mitigation efforts would have the largest benefits in preventing glacier melt. These source regions are also places where reducing the uncertainty in BC emissions is most critical. Currently, substantial uncertainty exists in both emission factors and activity rates, especially in India and China. Though very difficult to quantify, the $95 \%$ confidence interval for emission estimates can include a range that varies by more than a factor of four (Bond et al., 2004). In addition to the recognized hot spots of both overall emissions and emissions contributions to the Third Pole (e.g. northern India and central China), our study identified the Middle East as a substantial contributor to $\mathrm{BC}$ in Asian glaciers (up to 3 tonnes per day in summer at Mt. Muztagh), despite not being an emissions hot spot in current inventories.

An important extension of this work would be to perform similar adjoint analyses using different meteorological fields or different global and high resolution regional models, to test the robustness of our results. A climate extension of our radiative forcing calculation would be to compute the resulting temperature change and the change in rate of snow melt due to $\mathrm{BC}$ deposition in the region. Disaggregation of the contributions of different emission sectors (e.g. diesel transport, residential combustion etc.) to deposition of $\mathrm{BC}$ at the Third Pole would also help guide the development of optimal mitigation strategies. So far, BC mitigation has been primarily motivated by air quality benefits. Our analysis and its possible extensions can help inform mitigation efforts to slow the rate of glacial melt by identifying regions that make the largest contributions to $\mathrm{BC}$ deposition in the region.

Acknowledgements. We thank the Geophysical Fluid Dynamics Laboratory for computational resources. We are pleased to acknowledge funding from the Science, Technology and Environmental Policy (STEP) program at the Woodrow Wilson School of Public and International Affairs at Princeton University.

Edited by: N. Riemer

\section{References}

Allen, R. J. and Sherwood, S. C.: Aerosol-cloud semi-direct effect and land-sea temperature contrast in a $\mathrm{gcm}$, Geophys. Res. Lett., 37, L07702, doi:10.1029/2010g1042759, 2010.

Aunan, K., Berntsen, T. K., Myhre, G., Rypdal, K., Streets, D. G., Woo, J.-H., and Smith, K. R.: Radiative forcing from household fuel burning in asia, Atmos. Environ., 43, 5674-5681, doi:10.1016/j.atmosenv.2009.07.053 2009.

Bauer, S. E., Menon, S., Koch, D., Bond, T. C., and Tsigaridis, K.: A global modeling study on carbonaceous aerosol microphysical characteristics and radiative forcing, Atmos. Chem. Phys., 10, 7439-7456, doi:10.5194/acp-10-7439-2010, 2010.

Bey, I., Jacob, D. J., Yantosca, R. M., Logan, J. A., Field, B. D., Fiore, A. M., Li, Q., Liu, H. Y., Mickley, L. J., and Schultz, M. G.: Global modeling of tropospheric chemistry with assimilated meteorology: Model description and evaluation, J. Geophys. Res., 106, 23073-23096, 2001.

Bond, T. C., Streets, D. G., Yarber, K. F., Nelson, S. M., Woo, J. H., and Klimont, Z.: A technology-based global inventory of black and organic carbon emissions from combustion, J. Geophys. Res.-Atmos., 109, D14203, doi:10.1029/2003jd003697, 2004.

Bond, T. C., Bhardwaj, E., Dong, R., Jogani, R., Jung, S. K., Roden, C., Streets, D. G., and Trautmann, N. M.: Historical emissions of black and organic carbon aerosol from energy-related combustion, 1850-2000, Global Biogeochemi. Cy., 21, GB2018, doi:10.1029/2006gb002840, 2007.

Chen, W. T., Lee, Y. H., Adams, P. J., Nenes, A., and Seinfeld, J. H.: Will black carbon mitigation dampen aerosol indirect forcing?, Geophys. Res. Lett., 37, L09801, doi:10.1029/2010g1042886, 2010.

Fisher, J. A., Jacob, D. J., Purdy, M. T., Kopacz, M., Le Sager, P., Carouge, C., Holmes, C. D., Yantosca, R. M., Batchelor, R. L., Strong, K., Diskin, G. S., Fuelberg, H. E., Holloway, J. S., Hyer, E. J., McMillan, W. W., Warner, J., Streets, D. G., Zhang, Q., Wang, Y., and Wu, S.: Source attribution and interannual variability of arctic pollution in spring constrained by aircraft (arctas, arcpac) and satellite (airs) observations of carbon monoxide, Atmos. Chem. Phys, 10, 977-996, doi:10.5194/acp-10-977-2010, 2010.

Flanner, M. G. and Zender, C. S.: Linking snowpack microphysics and albedo evolution, J. Geophys. Res., 111, D12208, doi:10.1029/2005jd006834, 2006.

Flanner, M. G., Zender, C. S., Randerson, J. T., and Rasch, P. J.: Present-day climate forcing and response from black carbon in snow, J. Geophys. Res.-Atmos., 112, D11202, doi:10.1029/2006jd008003, 2007.

Flanner, M. G., Zender, C. S., Hess, P. G., Mahowald, N. M., Painter, T. H., Ramanathan, V., and Rasch, P. J.: Springtime warming and reduced snow cover from carbonaceous particles, Atmos. Chem. Phys., 9, 2481-2497, doi:10.5194/acp-9-24812009, 2009.

Forster, P., Ramaswamy, V., Artaxo, P., Berntsen, T., Betts, R. Fahey, D. W., Haywood, J., Lean, J., Lowe, D. C., Myhre, G., Nganga, J., Prinn, R., Raga, G., Schulz, M., van Dorland, R., Bodeker, G., Boucher, O., Collins, W. D., Conway, T. J., Dlugokencky, E., Elkins, J. W., Etheridge, D., Foukal, P., Fraser, P., Geller, M., Joos, F., Keeling, C. D., Kinne, S., Lassey, K., Lohmann, U., Manning, A. C., Montzka, S., Oram, D., 
O’Shaughnessy, K., Piper, S., Plattner, G.-K., Ponater, M., Ramankutty, N., Reid, G., Rind, D., Rosenlof, K., Sausen, R., Schwarzkopf, D., Solanki, S. K., Stenchikov, G., Stuber, N., Takemura, T., Textor, C., Wang, R., Weiss, R., and Whorf, T.: Changes in Atmospheric Constituents and in Radiative Forcing, in: Climate Change 2007: The Physical Science Basis. Contribution of Working Group I to the 4th Assessment Report of the Intergovernmental Panel on Climate Change Cambridge University Press, Cambridge, United Kingdom and New York, USA, 2007.

$\mathrm{Fu}, \mathrm{Q}$. and Liou, K. N.: Parameterization of the radiative properties of cirrus clouds, J. Atmos. Sci., 50, 2008-2025, 1993.

Hansen, J. and Nazarenko, L.: Soot climate forcing via snow and ice albedo, P. Natl. Acad. Sci. USA, 101, 423-428, doi:10.1073/pnas.2237157100, 2004.

Hansen, J., Sato, M., Ruedy, R., Nazarenko, L., Lacis, A., Schmidt, G. A., Russell, G., Aleinov, I., Bauer, M., Bauer, S., Bell, N., Cairns, B., Canuto, V., Chandler, M., Cheng, Y., Del Genio, A., Faluvegi, G., Fleming, E., Friend, A., Hall, T., Jackman, C., Kelley, M., Kiang, N., Koch, D., Lean, J., Lerner, J., Lo, K., Menon, S., Miller, R., Minnis, P., Novakov, T., Oinas, V., Perlwitz, J., Perlwitz, J., Rind, D., Romanou, A., Shindell, D., Stone, P., Sun, S., Tausnev, N., Thresher, D., Wielicki, B., Wong, T., Yao, M., and Zhang, S.: Efficacy of climate forcings, J. Geophys. Res.Atmos., 110, D18104, doi:10.1029/2005JD005776, 2005.

Heald, C. L., Daniel, J. J., Arlene, M. F., Louisa, K. E., John, C. G., Merritt, N. D., Juying, W., David, P. E., James, H. C., Amy, J. H., Glen, W. S., Edward, V. B., Melody, A. A., Stephanie, A. V., David, J. W., Donald, R. B., Hanwant, B. S., Scott, T. S., Robert, W. T., and Fuelberg, H. E.: Asian outflow and transpacific transport of carbon monoxide and ozone pollution: An integrated satellite, aircraft, and model perspective, J. Geophys. Res., 108, 4804, 10.1029/2003JD003507, 2003.

Henze, D. K., Hakami, A., and Seinfeld, J. H.: Development of the adjoint of GEOS-Chem, Atmos. Chem. Phys., 7, 2413-2433, doi:10.5194/acp-7-2413-2007, 2007.

Henze, D. K., Seinfeld, J. H., and Shindell, D. T.: Inverse modeling and mapping US air quality influences of inorganic $\mathrm{PM}_{2.5}$ precursor emissions using the adjoint of GEOS-Chem, Atmos. Chem. Phys., 9, 5877-5903, doi:10.5194/acp-9-5877-2009, 2009.

Jacobson, M. Z.: Strong radiative heating due to the mixing state of black carbon in atmospheric aerosols, Nature, 409, 695-697, 2001.

Koch, D., Bond, T. C., Streets, D., Unger, N., and van der Werf, G. R.: Global impacts of aerosols from particular source regions and sectors, J. Geophys. Res.-Atmos., 112, D02205, doi:10.1029/2005jd007024, 2007.

Koch, D., Menon, S., Del Genio, A., Ruedy, R., Alienov, I., and Schmidt, G. A.: Distinguishing aerosol impacts on climate over the past century, J. Climate, 22, 2659-2677, doi:10.1175/2008JCLI2573.1, 2009a.

Koch, D., Schulz, M., Kinne, S., McNaughton, C., Spackman, J. R., Balkanski, Y., Bauer, S., Berntsen, T., Bond, T. C., Boucher, O., Chin, M., Clarke, A., De Luca, N., Dentener, F., Diehl, T., Dubovik, O., Easter, R., Fahey, D. W., Feichter, J., Fillmore, D., Freitag, S., Ghan, S., Ginoux, P., Gong, S., Horowitz, L., Iversen, T., Kirkevåg, A., Klimont, Z., Kondo, Y., Krol, M., Liu, X., Miller, R., Montanaro, V., Moteki, N., Myhre, G., Penner, J. E.,
Perlwitz, J., Pitari, G., Reddy, S., Sahu, L., Sakamoto, H., Schuster, G., Schwarz, J. P., Seland, Ø., Stier, P., Takegawa, N., Takemura, T., Textor, C., van Aardenne, J. A., and Zhao, Y.: Evaluation of black carbon estimations in global aerosol models, Atmos. Chem. Phys., 9, 9001-9026, doi:10.5194/acp-9-9001-2009, 2009. b.

Koelemeijer, R. B. A., de Haan, J. F., and Stammes, P.: A database of spectral surface reflectivity in the range 335-772 nm derived from 5.5 years of gome observations, J. Geophys. Res., 108, 4070, doi:10.1029/2002JD002429, 2003.

Kopacz, M., Jacob, D. J., Henze, D. K., Heald, C. L., Streets, D. G., and Zhang, Q.: Comparison of adjoint and analytical bayesian inversion methods for constraining asian sources of carbon monoxide using satellite (mopitt) measurements of co columns, J. Geophys. Res., 114, D04305, doi:10.1029/2007JD009264, 2009.

Kopacz, M., Jacob, D. J., Fisher, J. A., Logan, J. A., Zhang, L., Megretskaia, I. A., Yantosca, R. M., Singh, K., Henze, D. K., Burrows, J. P., Buchwitz, M., Khlystova, I., McMillan, W. W., Gille, J. C., Edwards, D. P., Eldering, A., Thouret, V., and Nedelec, P.: Global estimates of CO sources with high resolution by adjoint inversion of multiple satellite datasets (MOPITT, AIRS, SCIAMACHY, TES), Atmos. Chem. Phys., 10, 855-876, doi:10.5194/acp-10-855-2010, 2010.

Kopp, R. E. and Mauzerall, D. L.: Assessing the climatic benefits of black carbon mitigation, PNAS, 107(26), 11703-11708, doi:10.1073/pnas.0909605107, 2010.

Li, Q., Jacob, D. J., Bey, I., Palmer, P. I., Duncan, B. N., Field, B. D., Martin, R. V., Fiore, A. M., Yantosca, R. M., Parrish, D., D., Simmonds, P. G., and Oltmans, S. J.: Transatlantic transport of pollution and its effects on surface ozone in europe and north america, J. Geophys. Res., 107, 4166, doi:10.1029/2001JD001422, 2002.

Liou, K. N., Fu, Q., and Ackereman, T. P.: A simple formulation of the d-four-stream approximation for radiative transfer parameterizations, J. Atmos. Sci., 45, 1940-1947, 1988.

Liu, J., Fan, S.-M., Horowitz, L. W., and Levy, H. I.: Factors controlling long-range transport of black carbon to the arctic, J. Geophys. Res., 116, D04307, doi:10.1029/2010JD015145, 2011.

Marinoni, A., Cristofanelli, P., Laj, P., Duchi, R., Calzolari, F., Decesari, S., Sellegri, K., Vuillermoz, E., Verza, G. P., Villani, P., and Bonasoni, P.: Aerosol mass and black carbon concentrations, two year-round observations at NCO-P (5079 m, Southern Himalayas), Atmos. Chem. Phys. Discuss., 10, 8379-8413, doi:10.5194/acpd-10-8379-2010, 2010.

Menon, S., Koch, D., Beig, G., Sahu, S., Fasullo, J., and Orlikowski, D.: Black carbon aerosols and the third polar ice cap, Atmos. Chem. Phys., 10, 4559-4571, doi:10.5194/acp-10-4559-2010, 2010.

Ming, J., Cachier, H., Xiao, C., Qin, D., Kang, S., Hou, S., and $\mathrm{Xu}, \mathrm{J}$.: Black carbon record based on a shallow Himalayan ice core and its climatic implications, Atmos. Chem. Phys., 8, 13431352, doi:10.5194/acp-8-1343-2008, 2008.

Ming, J., Xiao, C. D., Cachier, H., Qin, D. H., Qin, X., Li, Z. Q., and $\mathrm{Pu}$, J. C.: Black carbon (bc) in the snow of glaciers in west china and its potential effects on albedos, Atmos. Res., 92, 114-123, doi:10.1016/j.atmosres.2008.09.007, 2009.

Park, R. J., Jacob, D. J., Palmer, P. I., Clarke, A. D., Weber, R. J., Zondlo, M. A., Eisele, F. L., Bandy, A. R., Thornton, D. C., Sachse, G. W., and Bond, T. C.: Export efficiency of black carbon aerosol in continental outflow: Global implications, J. Geophys. 
Res.-Atmos., 110, D11205, doi:10.1029/2004jd005432, 2005.

Quinn, P. K., Bates, T. S., Baum, E., Doubleday, N., Fiore, A. M., Flanner, M., Fridlind, A., Garrett, T. J., Koch, D., Menon, S., Shindell, D., Stohl, A., and Warren, S. G.: Short-lived pollutants in the Arctic: their climate impact and possible mitigation strategies, Atmos. Chem. Phys., 8, 1723-1735, doi:10.5194/acp8-1723-2008, 2008.

Ramana, M. V., Ramanathan, V., Feng, Y., Yoon, S.-C., Kim, S.W., Carmichael, G. R., and Schauer, J. J.: Warming influenced by the ratio of black carbon to sulphate and the black-carbon source, Nat. Geosci., 3(8), 542-545, 2010.

Ramanathan, V. and Carmichael, G.: Global and regional climate changes due to black carbon, Nat. Geosci., 1, 221-227, doi:10.1038/ngeo156, 2008.

Shindell, D. and Faluvegi, G.: Climate response to regional radiative forcing during the twentieth century, Nat. Geosci., 2(4), 294 300, 2009

Shindell, D. T., Levy, H., Schwarzkopf, M. D., Horowitz, L. W., Lamarque, J. F., and Faluvegi, G.: Multimodel projections of climate change from short-lived emissions due to human activities, J. Geophys. Res.-Atmos., 113, D11109, doi:10.1029/2007jd009152, 2008.

van der Werf, G. R., Randerson, J. T., Giglio, L., Collatz, G. J., Kasibhatla, P. S., and Arellano Jr., A. F.: Interannual variability in global biomass burning emissions from 1997 to 2004, Atmos. Chem. Phys., 6, 3423-3441, doi:10.5194/acp-6-3423-2006, 2006.

Vignati, E., Karl, M., Krol, M., Wilson, J., Stier, P., and Cavalli, F.: Sources of uncertainties in modelling black carbon at the global scale, Atmos. Chem. Phys., 10, 2595-2611, doi:10.5194/acp-102595-2010, 2010.

Wang, J. and Christopher, S. A.: Mesoscale modeling of central American smoke transport to the united states, 2: Smoke regional radiative impacts on surface energy budget and boundary layer evolution, J. Geophys. Res., 111, D14S92, doi:10.1029/2005JD006720, 2006.

Wang, J. and Martin, S. T.: Satellite characterization of urban aerosols: Importance of including hygroscopicity and mixing state in the retrieval algorithms, J. Geophys. Res., 112, D06301, doi:10.1029/2006JD008078, 2007.
Wang, J., Nair, U., and Christopher, S. A.: Goes-8 aerosol optical thickness assimilation in a mesoscale model: Online integration of aerosol radiative effects, J. Geophys. Res., 109, D23203, doi:10.1029/2004JD004827, 2004.

Wang, J., Jacob, D. J., and Martin, S. T.: Sensitivity of sulfate direct climate forcing to the hysteresis of particle phase transitions, J. Geophys. Res.-Atmos., 113, D11207, doi:10.1029/2007JD009368, 2008.

Warren, S. G. and Wiscombe, W. J.: Dirty snow after nuclear war, Nature, 313, 467-470, 1985.

$\mathrm{Xu}, \mathrm{B}$., Yao, T., Liu, X., and Wang, N.: Elemental and organic carbon measurements with a two-step heating-gas chromatography system in snow samples from the tibetan plateau, Ann. Glaciol., 43, 257-262, doi:10.3189/172756406781812122, 2006.

Xu, B.-Q., Wang, M., Joswiak, D. R., Cao, J.-J., Yao, T.-D., Wu, G.-J., Yang, W., and Zhao, H.-B.: Deposition of anthropogenic aerosols in a southeastern tibetan glacier, J. Geophys. Res., 114, D17209, doi:10.1029/2008JD011510, 2009a.

Xu, B., Cao, J., Hansen, J., Yao, T., Joswiak, D. R., Wang, N., Wu, G.-J., Wang, M., Zhao, H.-B., Yang, W., Liu, $\mathrm{X}$., and He, J.: Black soot and the survival of tibetan glaciers, P. Natl. Acad. Sci. USA, 106(52), 22114-22118, doi:10.1073/pnas.pnas.0910444106, 2009b.

Zhang, L., Jacob, D. J., Boersma, K. F., Jaffe, D. A., Olson, J. R., Bowman, K. W., Worden, J. R., Thompson, A. M., Avery, M. A., Cohen, R. C., Dibb, J. E., Flock, F. M., Fuelberg, H. E., Huey, L. G., McMillan, W. W., Singh, H. B., and Weinheimer, A. J.: Transpacific transport of ozone pollution and the effect of recent Asian emission increases on air quality in North America: an integrated analysis using satellite, aircraft, ozonesonde, and surface observations, Atmos. Chem. Phys., 8, 6117-6136, doi:10.5194/acp-8-6117-2008, 2008.

Zhang, L., Jacob, D. J., Kopacz, M., Henze, D. K., Singh, K., and Jaffe, D. A.: Intercontinental source attribution of ozone pollution at western us sites using an adjoint method, Geophys. Res. Lett., 36, L11810, doi:10.1029/2009g1037950, 2009. 